\title{
Variability of aerosol vertical distribution in the Sahel
}

\author{
O. Cavalieri ${ }^{1}$, F. Cairo ${ }^{1}$, F. Fierli ${ }^{1}$, G. Di Donfrancesco ${ }^{2}$, M. Snels ${ }^{1}$, M. Viterbini $^{1}$, F. Cardillo $^{1}$, B. Chatenet $^{3}$, \\ P. Formenti ${ }^{3}$, B. Marticorena ${ }^{3}$, and J. L. Rajot ${ }^{4}$ \\ ${ }^{1}$ Consiglio Nazionale delle Ricerche-Istituto di Scienze dell'Atmosfera e del Clima, Rome, Italy \\ ${ }^{2}$ Ente per le Nuove Tecnologie Energia e Ambiente, Frascati, Italy \\ ${ }^{3}$ LISA, Universités Paris Est-Paris Diderot-Paris 7, CNRS, Créteil, France \\ ${ }^{4}$ IRD-UMR 211 Bioemco, Niamey, Niger
}

Received: 18 May 2010 - Published in Atmos. Chem. Phys. Discuss.: 21 July 2010

Revised: 16 November 2010 - Accepted: 17 November 2010 - Published: 16 December 2010

\begin{abstract}
In this work, we have studied the seasonal and inter-annual variability of the aerosol vertical distribution over Sahelian Africa for the years 2006, 2007 and 2008, characterizing the different kind of aerosols present in the atmosphere in terms of their optical properties observed by ground-based and satellite instruments, and their sources searched for by using trajectory analysis. This study combines data acquired by three ground-based micro lidar systems located in Banizoumbou (Niger), Cinzana (Mali) and M'Bour (Senegal) in the framework of the African Monsoon Multidisciplinary Analysis (AMMA), by the AEROsol RObotic NETwork (AERONET) sun-photometers and by the space-based Cloud-Aerosol Lidar with Orthogonal Polarization (CALIOP) onboard the CALIPSO satellite (CloudAerosol Lidar and Infrared Pathfinder Observations).

During winter, the lower levels air masses arriving in the Sahelian region come mainly from North, North-West and from the Atlantic area, while in the upper troposphere air flow generally originates from West Africa, crossing a region characterized by the presence of large biomass burning sources. The sites of Cinzana, Banizoumbou and M'Bour, along a transect of aerosol transport from East to West, are in fact under the influence of tropical biomass burning aerosol emission during the dry season, as revealed by the seasonal pattern of the aerosol optical properties, and by backtrajectory studies.
\end{abstract}

Aerosol produced by biomass burning are observed mainly during the dry season and are confined in the upper layers of the atmosphere. This is particularly evident for 2006, which was characterized by a large presence of biomass burning aerosols in all the three sites.

Correspondence to: F. Cairo (francesco.cairo@artov.isac.cnr.it)
Biomass burning aerosol is also observed during spring when air masses originating from North and East Africa pass over sparse biomass burning sources, and during summer when biomass burning aerosol is transported from the southern part of the continent by the monsoon flow.

During summer months, the entire Sahelian region is under the influence of Saharan dust aerosols: the air masses in low levels arrive from West Africa crossing the Sahara desert or from the Southern Hemisphere crossing the Guinea Gulf while in the upper layers air masses still originate from North, North-East. The maximum of the desert dust activity is observed in this period which is characterized by large AOD (above 0.2) and backscattering values. It also corresponds to a maximum in the extension of the aerosol vertical distribution (up to $6 \mathrm{~km}$ of altitude). In correspondence, a progressive cleaning up of the lowermost layers of the atmosphere is occurring, especially evident in the Banizoumbou and Cinzana sites.

Summer is in fact characterized by extensive and fast convective phenomena.

Lidar profiles show at times large dust events loading the atmosphere with aerosol from the ground up to $6 \mathrm{~km}$ of altitude. These events are characterized by large total attenuated backscattering values, and alternate with very clear profiles, sometimes separated by only a few hours, indicative of fast removal processes occurring, likely due to intense convective and rain activity.

The inter-annual variability in the three year monitoring period is not very significant. An analysis of the aerosol transport pathways, aiming at detecting the main source regions, revealed that air originated from the Saharan desert is present all year long and it is observed in the lower levels of the atmosphere at the beginning and at the end of the year. In the central part of the year it extends upward and the lower

Published by Copernicus Publications on behalf of the European Geosciences Union. 
levels are less affected by air masses from Saharan desert when the monsoon flow carries air from the Guinea Gulf and the Southern Hemisphere inland.

\section{Introduction}

Africa is the world's largest source of biomass burning aerosol (BBA) and desert dust (DD), which constitute the majority of aerosol present in the Sahelian region (Prospero et al., 2002). Satellite imagery shows frequent and vast plumes of dust and smoke emerging from Africa and spanning the entire tropical Atlantic and Mediterranean region. Both dust and biomass burning aerosols influence the Earth's radiative budget by scattering and absorbing solar radiation (Haywood and Boucher, 2000; Eck et al., 2003; Magi et al., 2003; Haywood et al., 2003). Moreover, dust particles are sufficiently large to interact directly with terrestrial radiation as well (Foster et al., 2007). The pattern of aerosol emissions, particularly biomass burning smoke, over West Africa follows a well determined seasonal cycle related to the seasonal shift of the Inter-Tropical Convergence Zone (ITCZ) which moves northward and crosses $15^{\circ} \mathrm{N}$ by the end of June and retreats southward again in September. Maximum emissions of biomass burning aerosol from the regions of Northern Africa occur during the dry season from December to February with only few biomass burning episodes occurring during August-November (Haywood et al., 2008). Far from the sources, dust or biomass burning aerosols are frequently observed in elevated layers (Prospero and Carlson 1972; Ansmann et al., 2003). Dust storms occur throughout the whole year, peaking in springtime (Marticorena and Bergametti, 1996) while westward transport over the Atlantic Ocean, at peak during the summer as a result of large scale dust outbreaks, is mostly confined to a deep mixed layer (the Saharan Air Layer) (Léon et al., 2009; Prospero et Carlson 1972). Much of these dust aerosols are transported westward under the influence of the trade winds while northward transport toward the Mediterranean is linked to the presence of cyclones (Moulin et al., 1997; Alpert et al., 1990; Dayan et al., 1991). The zone of maximum dust transport shifts from $\sim 5^{\circ} \mathrm{N}$ during winter to $\sim 20^{\circ} \mathrm{N}$ during summer and it is associated with the latitudinal movement of the large-scale circulation, including that of the Intertropical Convergence Zone (Moulin et al., 1997). Long term aerosol studies have shown a seasonal pattern of the transport of African dust: during winter, the desert aerosols are transported across the Atlantic towards the north-eastern coast of South America (Swap et al., 1992) while during summer dust is transported more northward above the trade winds atmospheric layer and extends as far as the Caribbean sea and the south-eastern United States (Prospero and Carlson, 1972).

Several field campaigns have been conducted in Africa to study atmospheric particles and their optical properties and to understand the influence of these two types of aerosol on the regional climate. A classification of the physical and optical properties of mineral dust aerosols emitted from the African continent has been performed in the frame of the Saharan Dust Experiment (SHADE) that took place in late September 2000 (Tanrè et al., 2003).

Similarly, biomass burning aerosols emitted from South Africa were studied during Southern African Regional Science Initiative (SAFARI) field campaign conducted during the August-September 2000 dry season (Schmid et al., 2003; Magi et al., 2003; Haywood et al., 2003; Swap et al., 2003).

Recently in the frame of the African Monsoon Multidisciplinary Analysis (AMMA) project extensive multi-annual series of observations in Sahelian Africa were performed (Cairo et al., 2010). AMMA is an international project with the goal to improve the knowledge and the understanding of the Western African Monsoon, its variability on daily to inter-annual timescales and its influence on the physical, chemical and biological environment on a regional and global scale. AMMA involved three observation periods: the long term observation period (LOP) concerned with historical observations and additional long term observations (2001-2010) to study the inter-annual to decadal variability, the enhanced observation period (EOP) planned to serve as a link between LOP and more focused observations, during special observation periods (SOP). The EOP main objective was to document the annual cycle of the surface and atmospheric conditions over a climatic transect and to study the surface memory effects at the seasonal scale, over three years (2005-2007). The SOP periods took place in the West African Sahel in 2006 and focused on detailed observation of specific processes and weather systems during the dry season (SOP0, January-February) and at various key stages of the rainy season during three periods in summer 2006: the monsoon onset (SOP1, 15 May-30 June), the peak monsoon (SOP2, 1 July-14 August) and finally the late monsoon (SOP3, 15 August-15 September) (Redelsperger et al., 2006).

The identification and characterization of aerosol sources and the study of the evolution and the effects of atmospheric aerosols were among the objectives of the AMMA effort.

Ground-based measurements of aerosol mass, optical properties and vertical distribution over M'Bour, Senegal from 2006 to 2008 have been reported by Léon et al. (2009). The maximum in the dust activity was observed in summer (June-July) corresponding to a maximum in the aerosol optical thickness and single scattering albedo, although severe dust storms were also observed in spring (March). Sporadic events of biomass burning aerosols were observed in winter, particularly in January 2006.

Haywood et al. (2008), investigated tropospheric aerosol transport over West Africa and the associated meteorological conditions during the dry season, combining data from ultra-light aircraft borne-lidar, airborne in situ aerosol and gas measurements, satellite based aerosol measurements, air mass trajectories and radiosonde measurements. 
High concentrations of mineral dust aerosol were typically observed from the surface up to 1.5 or $2 \mathrm{~km}$ associated with Saharan air masses. At higher altitudes concentration of biomass burning aerosol were typically observed between 2$5 \mathrm{~km}$ of altitude (Johnson et al., 2008; Osborne et al., 2008; Raut and Chazette, 2008).

Heese and Wiegner (2008), reported lidar measurements of the vertical distribution of optical particle properties performed during January 2006 in Banizoumbou (Niger). The profiles show a varying dust layer in the planetary boundary layers during the whole period and frequently observed layer of biomass burning aerosol in the PBL and up to an altitude of $5 \mathrm{~km}$.

The objective of this paper is twofold: (1) to study the seasonal and inter-annual variability of aerosol optical properties and the aerosol vertical distribution in the Sahelian region over three years and (2) to characterize the different kind of aerosols observed by lidar in relation to the origin of the air masses arriving in the Sahel area.

The study of the inter-seasonal aerosol vertical distribution variability was conducted on the basis of the dataset collected in 2006 by three micro lidar systems (MULIDs) (Cavalieri et al., in press) deployed in M'Bour (Senegal), Cinzana (Mali) and Banizoumbou (Niger). We analyzed the spacebased lidar observations from CALIOP for the years 2006, 2007 and 2008 to characterize the inter-annual variability of the aerosol vertical profiles.

In order to characterize the different kind of aerosols present in the atmosphere, we have also used aerosol optical thickness and Ångström coefficient data obtained by sunphotometers located at three AEROsol RObotic NETwork (AERONET, Holben et al., 1998) stations. For the period of three years back-trajectories have been analyzed to identify the origin of the air masses sampled by ground based and satellite lidars. The biomass burning sources location and variability have been identified with fire products from the ATSR World Fire Atlas (Arino et al., 2001).

The paper is organized as follows: in Sect. 2 the optical parameters observed by different instruments are defined and discussed. Section 3 provides the analysis of aerosol seasonal patterns from MULID observations performed in Niger, Mali and Senegal sites in 2006. Section 4 presents the study of the aerosol inter-annual and intra-annual variability using measurements from the satellite lidar CALIOP over 2006, 2007 and 2008 (Winker et al., 2007). Section 5 depicts a general aerosol climatology linked to it to the general circulation patterns in the Sahel. Section 6 draws the conclusions of our study.

\section{Optical properties}

The elastic lidar is a robust system to retrieve the vertical profile of aerosol optical properties (Gobbi et al., 2000; Di Sarra et al., 2001; Di Donfrancesco et al., 2006;). The di- rectly accessible parameter is the attenuated backscattering coefficient $S(z)$, whose range corrected and energy normalized, equation is given by

$S(z)=K \beta(z) \exp \left(-2 \int_{0}^{z} \alpha(x) d x\right)$

where $z$ is the altitude/range, $\alpha$ and $\beta$ are respectively the extinction and backscattering coefficients, and $K$ is a constant.

The backscattering and extinction coefficients $\alpha$ and $\beta$ have contributions from both molecules (m) and aerosol (a).

$\alpha(z)=\alpha_{\mathrm{a}}(z)+\alpha_{\mathrm{m}}(z)$

$\beta(z)=\beta_{\mathrm{a}}(z)+\beta_{\mathrm{m}}(z)$

The backscatter ratio $R$ is defined as the ratio between the total backscattered radiation and the molecular backscatter:

$R=\left(\beta_{\mathrm{m}}+\beta_{\mathrm{a}}\right) / \beta_{\mathrm{m}}$

where $\beta_{\mathrm{m}}$ is the molecular backscatter and $\beta_{\mathrm{a}}$ is the aerosol backscatter coefficient. $\left(\beta_{\mathrm{m}}+\beta_{\mathrm{a}}\right)$ is proportional to the lidar signal while $\beta_{\mathrm{m}}$ is calculated from ancillary data, as radio sounding density profiles or atmospheric models.

Typical values for backscatter ratios for tropical atmospheres are around 4 in the lower layers up to $2 \mathrm{~km}$ and around 1.5 up to $6 \mathrm{~km}$ (Kim et al., 2009); conversely in polar region the backscatter values are reduced approximately to 1.5 in the lower layers and to 1.2 higher up (Stachelewska et al., 2010).

The aerosol and molecular lidar ratios are defined as

$$
L_{\mathrm{a}}(z)=\frac{\alpha_{\mathrm{a}}(z)}{\beta_{\mathrm{a}}(z)} \quad \text { and } \quad L_{\mathrm{m}}(z)=\frac{8 \pi}{3}
$$

The $L_{\mathrm{m}}$ is given by light scattering theory. The $L_{\mathrm{a}}$ varies widely depending on the aerosol size distribution, refractive index and shape. Typical values of the aerosol lidar ratio are below $30 \mathrm{sr}$ for maritime aerosols, from 30 to $50 \mathrm{sr}$ for mineral dust and around 60-70 sr for biomass burning aerosols. Both aerosol backscatter and extinction coefficient are variables in Eq. (1) and usually a lidar ratio is assumed to invert the lidar equation.

Although one often uses a fixed value for the aerosol lidar ratio, based on the kind of aerosol one expects, one might also vary this parameter in order to get a better agreement with other optical parameters obtained by co-located measurements of other optical instruments. The inversion applied here uses a variable lidar ratio that is selected for each lidar profile, in order to best fit with co-located Aerosol Optical Depth measurements taken by an AERONET sunphotometer. A detailed description of the method and the application to selected observations in Banizoumbou is reported in Cavalieri et al. (2011). 
The volume depolarization ratio $D$ is defined as the ratio between the parallel $\left(\beta^{/ /}\right)$and perpendicular $\left(\beta^{\perp}\right)$ polarization components:

$D=\frac{\beta^{\perp}}{\beta^{/ /}}$

Apart from a known contribution from the air molecules, $D$ has a variable contribution from the suspended aerosols and clouds, depending on the number, shape and size of the particles.

$D$ provides an indication of the particle shape and, to a lesser extent, of their size, because only non-spherical particles can produce a change in the polarization plane of the backscattered light (Reagan et al., 1989). Thus it allows to distinguish between spherical, small non spherical (i.e. biomass burning aerosol) and large non-spherical particles (i.e. mineral dust) (Mishchenko et al., 1997). Values close to zero are expected for spherical particles, and higher values are produced by non spherical particles.

In our analysis, we have used $R$ and $D$ to discriminate between biomass and dust aerosol (Balis et al., 2004; Heese and Wiegner 2008). Dust is characterized by a higher lidar ratio with values from 30 to $50 \mathrm{sr}$ and a volume depolarization greater than $10 \%$ (see for instance Mattis et al., 2002; De Tomasi et al., 2003; Tafuro et al., 2003; Cattrall et al., 2005; Immler and Schrems 2006; Mona et al., 2006) while BBA by a lidar ratio value $\sim 60-70 \mathrm{sr}$ and a volume depolarization often lower than 10\% (Ferrare et al., 2001; Fiebig et al., 2002; Wandinger et al., 2002; Balis et al., 2003; Cattrall et al., 2005).

The microphysical properties of aerosols are strongly correlated with the wavelength dependence of the extinction and backscatter coefficient. For the latter, such dependence is expressed in terms of the color index $C(z)$ expressed as:

$C(z)=\frac{-\ln \left(\beta_{\mathrm{a}}^{\lambda_{1}}(z) / \beta_{\mathrm{a}}^{\lambda_{2}}(z)\right)}{\ln \left(\lambda_{1} / \lambda_{2}\right)}$

where $\beta_{\mathrm{a}}^{\lambda 1}$ and $\beta_{\mathrm{a}}^{\lambda 2}$ denote the aerosol backscatter coefficient at wavelengths $\lambda_{1}$ and $\lambda_{2}$.

In this work $\lambda_{1}$ is equal to $532 \mathrm{~nm}$ and $\lambda_{2}$ to $1064 \mathrm{~nm}$ so that positive $C(z)$ indicates that aerosol backscatter decreases with increasing wavelength. The color index is used to retrieve qualitative information about the size of scattering particles since large $C(z)$ indicates the abundance of particles with radii smaller than the lidar wavelengths, whereas smaller $C(z)$ indicates the predominance of large particles (Liu and Mishchenko, 2001).

On the other hand, the color index can be used to identify dust aerosols since their wavelength dependency on the absorption properties causes $C(z)$ to become strongly negative while it remains around 0 for a non-absorbing aerosol (Immler and Schrems, 2003).

$C(z)$ close to 0 , as encountered in low level clouds, indicates the presence of particles much larger than the lidar wavelength. Based on these properties the color index has been used here as a tool to discriminate biomass burning aerosol from dust, the latter being generally larger in size $(>1 \mu \mathrm{m})$. The color index is typically below 0.5 for large dust particles (Ansmann et al., 2003) and in particular takes even smaller values for Saharan dust, while greater values indicate the presence of smaller particles $(<1 \mu \mathrm{m})$ (Balis et al., 2004; Rajot et al., 2008).

In order to quantify the overall aerosol abundance in the air column from the lidar profile and to compare it with integrated observations, the aerosol optical depth (AOD) has been used. This is defined as the integrated the aerosol extinction coefficient over a vertical column of unit cross section:

$\mathrm{AOD}=\int_{0}^{\infty} \alpha_{\mathrm{aer}}(z) d z$

and can be calculated both from lidar measurements, by integrating the extinction over the profile, and from sunphotometric observations (Devara et al., 1996). The AOD directly depends on the total aerosol mass, although it also depends on the size and refractive index of the particles. Similarly to the case of the spectral dependence of the backscatter coefficient, the wavelength, the AOD, and the atmospheric turbidity (haziness) are related through the Ångström' s turbidity formula:

$\mathrm{AOD}=B \lambda^{-A}$

where $B$ is the Ångström turbidity coefficient, $\lambda$ is the wavelength in microns, and $\mathrm{A}$ is the Ångström exponent. $A$ and $B$ are wavelength independent, and can be used to describe the size distribution of aerosol particles and the general haziness of the atmosphere. The Ångström exponent, defined in Eq. (8) can be obtained from

$A=\frac{\ln \left(\mathrm{AOD}_{1} / \mathrm{AOD}_{2}\right)}{\ln \left(\lambda_{2} / \lambda_{1}\right)}$

Larger values of A imply a relatively high ratio of small to large $(r>0.5 \mu \mathrm{m})$. When larger particles dominate the distribution, A gets smaller. Small aerosol particles such as biomass burning aerosols interact more strongly with the shorter wavelengths of the solar spectrum while mineral dust particles interact with the full solar spectrum approximately equally. Consequently, for biomass burning aerosol $A$ has values between 1 and 1.5 while for mineral dust it is typically close to zero (Johnson et al., 2008; Pelon et al., 2008). The mixing between these types of particles tend to change the Ångström coefficient in the range 0-1.5 (Hamonou et al., 1999).

The criteria used to classify the main types of aerosols are displayed in Table 1. 
Table 1. Classification of desert dust and biomass burning aerosol depending on Volume Depolarization Ratio $(D)$, Color Index $(C)$ and Ångström coefficient $(A)$ values.

\begin{tabular}{llll}
\hline Type of Aerosol & $D(\%)$ & $C$ & $A$ \\
\hline Desert Dust & $>10 \%$ & $<0.5$ & $\sim 0$ \\
Biomass Burning & $<10 \%$ & $0.5-3.0$ & $1.0-1.5$ \\
\hline
\end{tabular}

\section{Instrumentation}

\subsection{Mulid lidars}

Three microlidars (MULID) have been deployed along a longitudinal transect in the Sahelian region, where transport from the dust source regions toward West occurs, in M'Bour (Senegal, $14.23^{\circ} \mathrm{N}-16.57^{\circ} \mathrm{W}$ ), Cinzana (Mali, $13.16^{\circ} \mathrm{N}-$ $5.56^{\circ} \mathrm{W}$ ) and Banizoumbou (Niger, $13.5^{\circ} \mathrm{N}-2.6^{\circ} \mathrm{E}$ ) .

The MULID systems are newly developed portable low power consumption lidars adapted for a field use in a semiautomatic mode in remote sites powered only by solar panels.

The main optical and electronic MULID characteristics are listed in Table 2.

In Cinzana the lidar was located outside, close to a small building (scientific offices) of the Agronomical Research station of Cinzana, at about $2 \mathrm{~m}$ above the ground. In M'Bour station the lidar was positioned on the roof of a building at $10 \mathrm{~m}$ from the ground. Cinzana is a rural station, surrounded by open fields; the measurement station is hosted by the Station de Recherche Agronomique de Cinzana depending on the Institut d'Economie Rurale of Mali. In M'Bour, the lidar was installed at the Station de Geophysique of the Institut de Recherche pour le Developpement, inside a protected natural area, facing the Atlantic Ocean, south of the city of M'Bour (180000-200 000 inhabitants). Along with the lidar systems, the sites hosted a sunphotometer of Aeronet. The M'Bour site being one of the three super-sites implemented in Africa for the AMMA activities, was also equipped with particle counters, nephelometers and aethalometers for the SOP0 and with fluxmeters throughout the EOP.

The station in Banizoumbou hosted the MULID in a small hut. The station is located in the countryside at a distance of $60 \mathrm{~km}$ east from the capital of Niger, Niamey, and was a second super site for the AMMA project, hosting instruments for a complete characterization of the aerosol properties. This site has been operational since the early nineties, when the first measurements of soil erosion were performed on a cultivated field and a fallow (Rajot, 2001; Balis et al., 2004). A sunphotometer station AERONET is implemented nearby Banizoumbou since 1995 .

For the complete list and description of instruments placed in the Banizoumbou and M'Bour super sites the reader may refer to: http://amma.mediasfrance.org/implementation/ instruments/. Detailed descriptions of the instrumental set-
Table 2. Parameters of the MULID lidar.

\begin{tabular}{ll}
\hline Parameter & Value \\
\hline Wavelengths & $1064 \mathrm{~nm}$ and $532 \mathrm{~nm}$ \\
Laser Type & Nd: YAG \\
Pulse duration & $10 \mathrm{~ns}$ \\
Laser repetition rate & $0.3 \mathrm{~Hz}$ \\
Laser output energy & $10 \mathrm{~mJ}$ at $1064 \mathrm{~nm}$ \\
& $5 \mathrm{~mJ}$ at $532 \mathrm{~nm}$ \\
Telescope diameter & $20 \mathrm{~cm}$ \\
Telescope type & Newtonian f/1.5 \\
Telescope field of view & 0.666 mrad \\
Beam divergence & $0.5 \mathrm{mrad}$, full angle \\
& $4 \times$ expanded \\
Effective Filter bandwidth & $2 \mathrm{~nm}$ \\
Raw data resolution & $30 \mathrm{~m}$ photo-counting \\
& $3.75 \mathrm{~m}$ analog mode \\
Processed data resolution & $30 \mathrm{~m}$ \\
Full overlap & $600 \mathrm{~m}$ \\
Mali and Senegal systems & $20 \mathrm{~m}$ \\
Niger system & \\
\hline
\end{tabular}

up and the data inversion algorithm are given in Cavalieri et al. (2011) and, hence, here only a brief account on these will be given.

Let $S^{\prime}(z)$ be the range corrected and background subtracted signal. The total attenuated backscattering ratio $R^{\prime}$ defined as $R^{\prime}(z)=K_{R} S^{\prime}(z) / \beta_{\mathrm{m}}$ was obtained by iteratively correcting $R^{\prime}$ for cloud, aerosol and molecular attenuation until convergence to a stable value $R$ was reached. The coefficient $K_{R}$ has been chosen to impose $R^{\prime}(z)=1$ in a region of the atmosphere supposedly free of aerosols.

The MULIDs have been installed at the end of January 2006 and have provided daily observations for 2006 except for periods not covered by measurements due to problems with the laser heads, whose flashlamps experienced a fast degradation and had to be replaced. Backscatter and depolarization profiles with $30 \mathrm{~m}$ vertical resolution at two measurement sessions at fixed hours in the morning and in the evening, each session lasting $1 \mathrm{~h}$, were performed. During SOPs, additional measurement sessions were performed often in coincidence with other campaign activities, such as aircraft overpasses, to provide full daily coverage.

AOD was retrieved by integrating the extinction profile from the bottom to the top of the MULIDs sounding.

\subsection{CALIOP lidar}

The CALIPSO satellite hosts various instruments (more information at http://eosweb.larc.nasa.gov/PRODOCS/calipso/ tablecalipso.html), among others, the Cloud-Aerosol Lidar with Orthogonal Polarization (CALIOP). This elastic backscattering lidar provides information on the vertical 
distribution of aerosols and clouds as well as on their optical and physical properties over the globe (Winker et al., 2007).

Observations of total and perpendicular attenuated backscattering intensity at $532 \mathrm{~nm}$ and total attenuated backscattering intensity at 1064 are available on http:// eosweb.larc.nasa.gov/HBDOCS/langley_web_tool.html and analyzed in this study. The vertical resolution is $30 \mathrm{~m}$ and $60 \mathrm{~m}$ and the horizontal resolution $333 \mathrm{~m}$ and $1 \mathrm{~km}$ for altitudes between $-0.5 \mathrm{~km}$ and $8.2 \mathrm{~km}$ and between 8.2 and $20.2 \mathrm{~km}$, respectively. The backscatter coefficient profiles were derived from the calibrated, range corrected, laser energy normalized, background noise subtracted lidar return signal (Winker et al., 2007; Kim et al., 2009). The aerosol depolarization ratio (Cairo et al., 1999) is calculated as the ratio between perpendicular and parallel polarized backscatter signal at $532 \mathrm{~nm}$. The color ratio is calculated with Eq. (6) with $\lambda_{1}=532 \mathrm{~nm}$ and $\lambda_{2}=1064 \mathrm{~nm}$.

For our study, for comparison with the data provided by the ground based stations, we have grouped the CALIOP measurements acquired in the latitudinal band $11^{\circ} \mathrm{N}-15^{\circ} \mathrm{N}$ into three sub-sets at different longitude (i) $0^{\circ} \mathrm{E}-5^{\circ} \mathrm{E}$, (ii) $5^{\circ} \mathrm{W}-10^{\circ} \mathrm{W}$, (iii) $15^{\circ} \mathrm{W}-20^{\circ} \mathrm{W}$. These regions covered the Sahelian transect, each one containing in its centre one of the three ground based stations where the MULIDs were hosted. For each satellite orbit, a single vertical profile has been created by averaging the nearest 20 CALIOP profiles to the selected locations. These profiles were smoothed in the vertical at intervals of $300 \mathrm{~m}$ from the surface to $8.2 \mathrm{~km}$.

The analysed dataset extends from 13 June 2006 to the end of 2008. Satellite passages occurred at around 1.30 GMT and 13.00 GMT for Banizoumbou, 02.00 GMT and 13.30 GMT for Cinzana, 02.00 GMT and 14.30 GMT for M'Bour regions.

\subsection{AERONET sunphotometers}

The field campaign activities have been supported by a network of passive radiometers which has been operative routinely in West Africa since 1995, within the activities of AERONET. This network of annually sky calibrated radiometers measures the direct solar radiance at eight wavelengths and sky radiance at four of those wavelengths, providing sufficient information to determine the aerosol size distribution and refractive index (Dubovik et al., 2000; Dubovik et al., 2002). This long-term, continuous and readily accessible database of aerosol optical, microphysical and radiative properties for aerosol research and characterization is available at: http://aeronet.gsfc.nasa.gov/.

There, globally distributed observations of spectral aerosol optical depth AOD at 440, 675, 870 and $1020 \mathrm{~nm}$ and Ångström coefficient $A$ data are available at three quality levels: level 1.0 (unscreened), level 1.5 (cloud-screened) and level 2.0 (cloud-screened and quality -assured). For most days data are available at the Banizoumbou, Cinzana and
Dakar sites for the year 2006, 2007 and 2008 from about 07:00 a.m to 05:00 p.m.

In this study, we used AOD data from level 2.0 and we interpolated the AOD data at 440 and $675 \mathrm{~nm}$ to obtain the equivalent $\mathrm{AOD}$ at $532 \mathrm{~nm}$, wavelength of lidar measurements, by using the AOD spectral dependence (Ångström, 1964) provided by

$\frac{\mathrm{AOD}_{532}}{\mathrm{AOD}_{\lambda}}=\left(\frac{532}{\lambda}\right)^{-A}$

The Ångström exponent A is calculated from Eq. (9), by using AOD values at wavelengths of 440 and $675 \mathrm{~nm}$.

\section{Air mass transport analysis}

Air mass back-trajectories have been used to identify main circulation patterns and their seasonal variability in the region under investigation. Trajectories calculated 7 days backward at different altitudes above three measurement sites were retrieved using the http://aeronet.gsfc.nasa.gov/ cgi-bin/bamgomas_interactive interactive web site. This support website for the AERONET program and for the Back trajectories, AERONET, MODIS, GOCART, MPLNET Aerosol Synergism (BANGOMAS) project used trajectories calculations based on a kinematic trajectories analysis utilizing assimilated gridded analysis data of the Global Modeling Assimilation Office (GMAO) at the NASA for the period of 1 January 2000-30 August 2007) and the National Centers for Environmental Prediction (NCEP) analyses from 31 August 2007 onward.

In order to identify biomass burning sources, the fire product ATSR World Fire Atlas is used to identify possible emission due to fires.

ATSR fire products are available from November 1995 to present on a global scale and with a monthly frequency.

We obtained data from the Advanced ATSR sensor onboard ENVISAT for the years 2006, 2007 and 2008.

In order to identify dust and monsoon circulation patterns, air parcel positions are also matched with two regions representative of desert dust sources and monsoon flow.

The region representative of desert dust source (called "Desert" in Sect. 5) is considered the area of the Sahara desert between $18^{\circ}-30^{\circ} \mathrm{N}$ of latitude and $10^{\circ} \mathrm{W}-40^{\circ} \mathrm{E}$ of longitude while the region representative of monsoon flow is the area of the Guinea Gulf between $20^{\circ} \mathrm{W}-0^{\circ} \mathrm{W}$ of latitude and $10^{\circ} \mathrm{W}-20^{\circ} \mathrm{E}$ of longitude (called further in this manuscript Atlantic Ocean).

\section{Seasonal variability}

Different transport regimes, aerosol sources and meteorological condition lead us to expect distinct burdens for specific kinds of aerosols throughout the year. Specifically, the intense biomass burning would increase the BBA through the 
dry season, while, the DDA are expected to be at maximum in the summer season, where a cleansing of the lower part of the atmosphere should also be expected due to the intense precipitation linked to the monsoon activity.

A statistically significant number of 144 cloud screened profiles (Cavalieri et al., 2010) of aerosol extinction the coefficient was collected by a MULID system from February to August 2006 at the Banizoumbou site in Niger and 48 profiles obtained from January to July 2006 for the Cinzana site in Mali allows to infer aerosol seasonal evolution during this period. A much smaller number of only 19 profiles measured at the M'Bour site in Senegal limits analysis to the dry season of 2006 at this location.

We define dry season the period January-February (Julian day 1-58), spring season the period March-May (Julian day 60-133), summer season the period 15 May-15 September (Julian day 135-258), autumn season the period OctoberNovember (Julian day 274-334) and finally winter season the period December-February (Julian day 335-60).

A synopsis of the MULID measurements is presented in Fig. 1. The first panel (a) shows colour coded extinction profiles as a function of time (expressed in Julian Day) and altitude for Banizoumbou (left panel), Cinzana (central panel) and M'Bour (right panel) during 2006. We display profiles only up $6 \mathrm{~km}$ as above that level we consider the aerosol contribution to the AOD to be negligible.

The second row (b) reports the aerosol mask which has been applied to highlight different kind of aerosols using the aerosol extinction coefficient $\alpha$ and volume depolarization $D$ values criterion characterizing different biomass and dust aerosol based on their different optical properties. Most of the observations can be associated with a moderate dust load, with $D>10 \%$ and $\alpha$ laying in the range between 0.1 and $0.2 \mathrm{~km}^{-1}$, and those are not highlighted in the panels for sake of clarity and are drawn in the picture as background values (black color). We have considered as intense dust events those with aerosols extinction coefficient values $\alpha>0.2 \mathrm{~km}^{-1}$ and volume depolarization $D>10 \%$ (marked in red in Fig. 1b). We have considered as biomass burning aerosol observations those with $\alpha$ values between 0.05 and $0.2 \mathrm{~km}^{-1}$ and $D<10 \%$ marked in green in Fig. 1b. Finally, observations characterized by $\alpha>0.2 \mathrm{~km}^{-1}$ and $D<10 \%$ values have been considered as events of mixing between dust and biomass aerosols marked in blue in Fig. $1 \mathrm{~b}$.

Panels in row (c) show the altitude range where the AOD increases from $10 \%$ to $90 \%$ of its total value. Each red triangle marks the altitude where AOD reaches its median value ( $50 \%$ of total) representative for the average altitude of the aerosol layers.

Finally, the panels in row (d) report the integrated AOD.

The AOD was computed by integrating the extinction profile from $6 \mathrm{~km}$ to ground level. As detailed in Cavalieri et al. (2011), the Niger mulid allowed a complete coverage of this altitude range due to different overlapping optical channels for close and far lidar ranges, while the extinction in the partial overlap region for the Mali and Senegal lidars was reconstructed by extending to the ground level the extinction detected at the lowest altitude where full overlap was reached $(600 \mathrm{~m})$. This may induce an error that was estimated to be of the order of $15 \%$ on the whole AOD. The error was derived by comparing the AOD retrieved under our assumptions with one computed under the assumption of an Aerosol Scale Height of $3 \mathrm{~km}$, as reported in (Léon et al., 2009) for the observations taken in M'Bour (Senegal). We did not use a lidar profile reconstruction based on the Aerosol Scale Height approach (i.e. by extending the full overlap data downward with an exponential scaling), because in the Niger dataset we seldom observed an exponential scaling of the aerosol content in the lowest altitude range.

In Banizoumbou, during the late dry season in February the aerosol content is generally low, with AOD between 0.1 and 0.2. Biomass burning aerosols are detected in the lowermost layers $(0.5-1.5 \mathrm{~km})$, tapering off with increasing altitude even if non negligible extinction values are observed up to $4 \mathrm{~km}$. The aerosol burden increases at the beginning of the summer season ( 15 May-15 September) and extends upward to $4-5 \mathrm{~km}$ altitude, mainly associated with moderate to intense dust burdens with AOD around 0.1-0.5, although occasional biomass burning aerosol can be discerned, extending between 3 and $4 \mathrm{~km}$. It is noteworthy that in general the aerosol tends to be present higher up in altitude and this is especially evident in May and June, when the lowermost layers are cleaner than in February. Remarkable are a few strong dust events lasting a few days around day 160 and 170 (mid June 2006), with significant dust burdens at low level in the atmosphere, causing a net increase in AOD values, reaching values as high as 2 .

From the database coverage it is difficult to infer when the transition between winter and summer regimes occurs.

At the Cinzana site (Fig. 1) the intra-annual variability follows a similar pattern, although there, the aerosol content is generally larger than in Banizoumbou causing a significant difference in extinction (row a) in the middle troposphere atmosphere and in the integrated AOD (row d) values, that can be probably attributed to a more frequent occurrence of dust events (row b) at this site with respect to Banizoumbou.

Over Cinzana, in January, mainly biomass burning aerosol have been observed between 1 and $5 \mathrm{~km}$ of altitude, corresponding with an AOD of about 0.5.

BBA are observed more episodically in the summer season in the same range altitude while a mixture of the two kind of aerosols is often observed.

Large dust events, characterized by high extinction values $\left(\alpha>0.2 \mathrm{~km}^{-1}\right)$ and large depolarization $(D>10 \%)$, have been observed during the summer season, although not extending as far down in altitude as in Niger, but rather remaining confined between $1-5 \mathrm{~km}$, still producing a tenfold increase in AOD. 

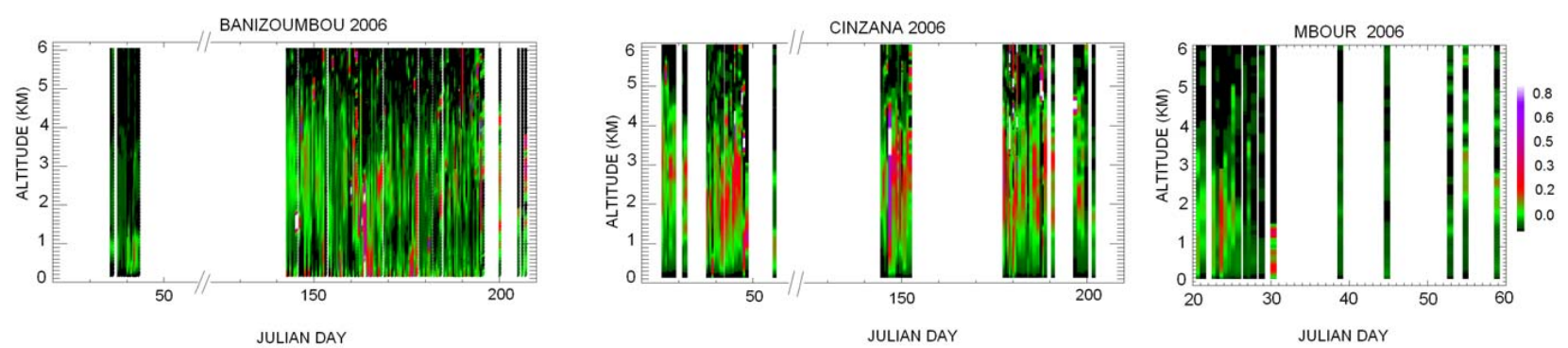

a)
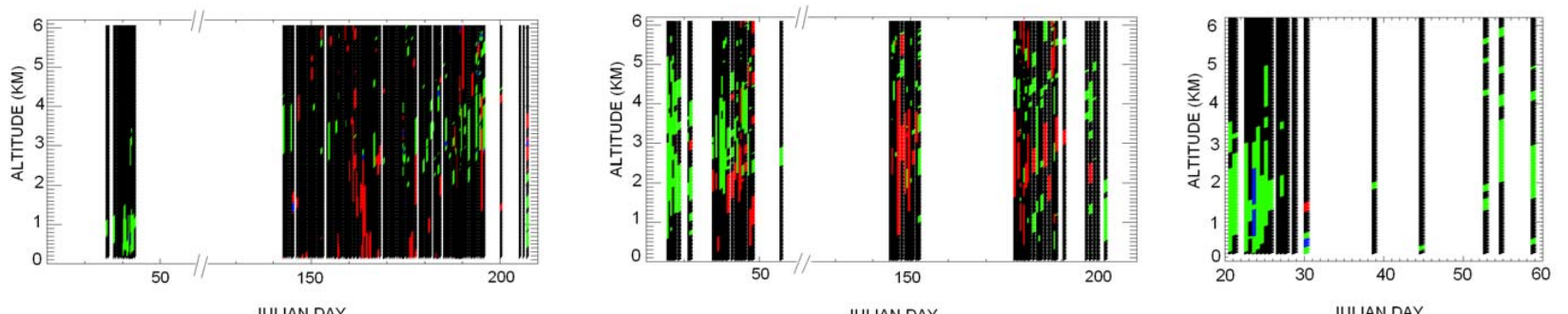

b)

JULIAN DAY
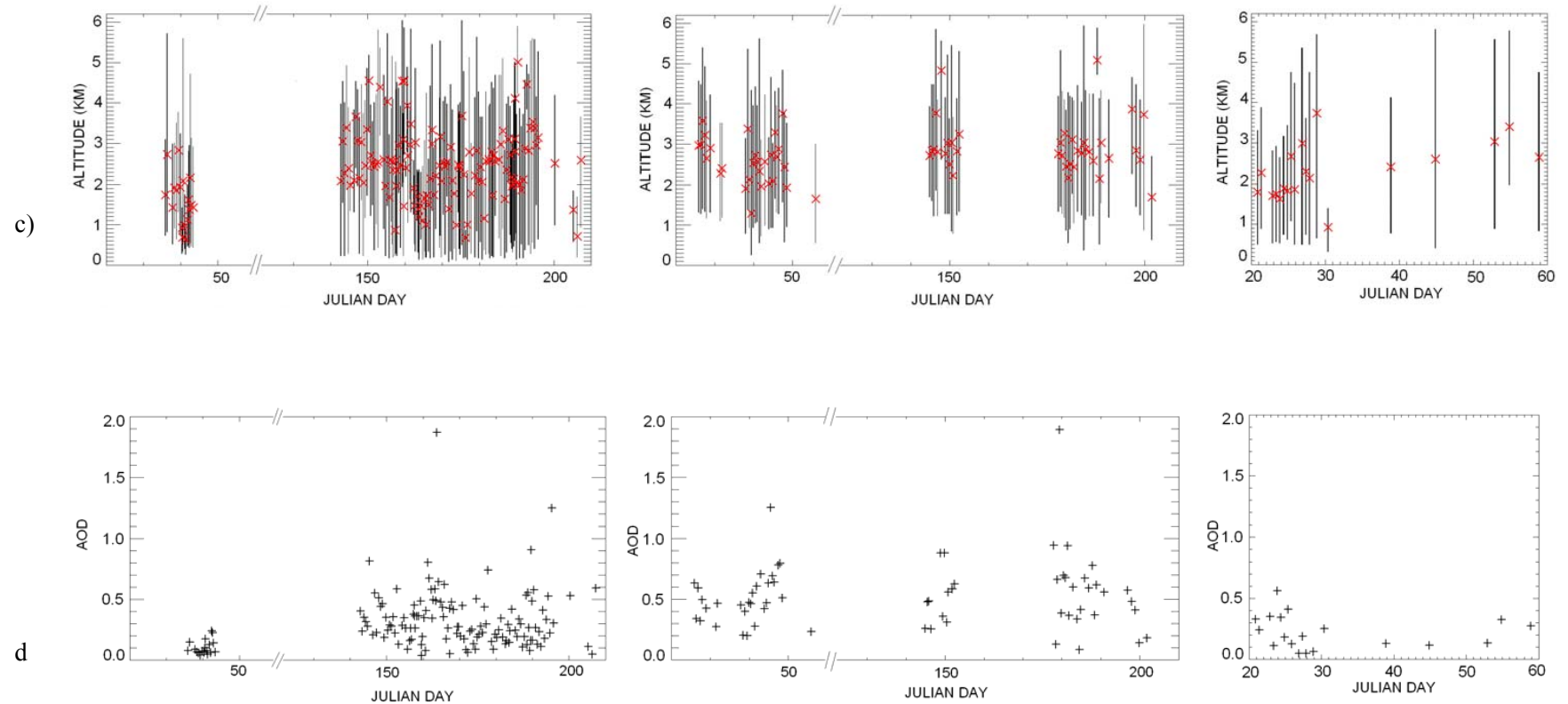

Fig. 1. MULID observations of aerosol extinction coefficient $\left(\mathrm{km}^{-1}\right)$ profiles (a), type of aerosol (b), aerosol occurrence vertical distribution (c), and aerosol optical depth (d) at three sites Banizoumbou in Niger (left column, 144 observations), Cinzana in Mali (middle column, 48 observations) and M'Bour in Senegal (right column, 19 observations) during 2006. In row (b) intense dust events (DD) are assigned in red, biomass burning aerosol (BBA) in green, mix of DD and BBA aerosols in blue and background aerosol in black. In row (c) top, bottom and barycentre (red cross) of vertical distribution of maximum aerosol load are given.

The difference in the presence of aerosol in the lowermost layers (i.e. below $1 \mathrm{~km}$ ) can be attributed to the fact that Banizoumbou is influenced by local dust sources (Rajot et al., 2008).

A moderate background of dust aerosol with extinction values around 0.1 and depolarization greater then $10 \%$ is often present throughout the year in both sites.
The aerosol observed in M'Bour station in January and February show the presence of biomass burning, between 1.5 and $4 \mathrm{~km}$. Occasionally, higher values of depolarization in the uppermost layers show the sporadic presence of dust aerosol. 

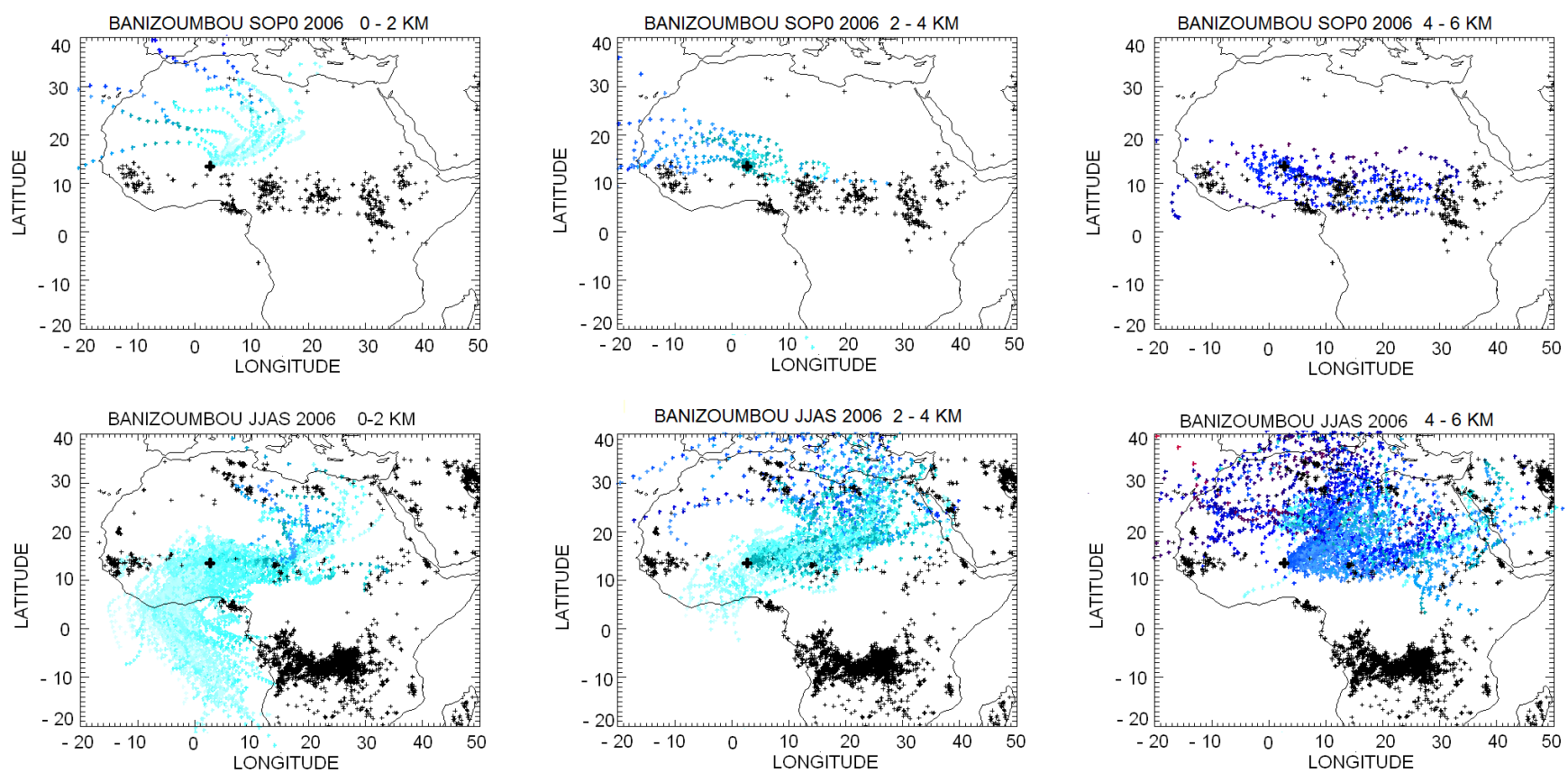

Fig. 2. Aeronet 7 day back -trajectories (blue dots) arriving at the Banizoumbou site between 0-2 km (left), 2-4 km (middle), 4-6 km (right) along with a biomass burning emission map (black cross) for the period January-February 2006 (upper row) and June-September 2006 (lower row).

In order to check the correctness of the classification of the aerosols based on lidar observations, the observed air masses have been linked to their origin, by using back-trajectories.

7 days back-trajectories are aggregated in clusters grouping arrival heights in three layers $(0-2 \mathrm{~km}, 2-4 \mathrm{~km}$, and $4-$ $6 \mathrm{~km}$ ) and are displayed (blue points) in Fig. 2, together with ATSR fires for 2006, indicated by black crosses.

During the dry season, air masses at low altitudes in Banizoumbou (Fig. 2) are mainly coming from the Sahara desert and from the Atlantic region (upper left panel), while at higher levels $(2-6 \mathrm{~km})$ the air parcels are confined in the Sahelian region matching most local biomass burning sources (upper right panel). This is somehow in partial contrast with the interpretation of the optical measurements. Lidar profiles show presence of biomass burning aerosols over the Banizoumbou site during the dry season in the lowermost levels (below $2 \mathrm{~km}$ ) but not in the upper layer as might be expected from the back-trajectories analysis.

However, our back-trajectory analysis is in good accordance with the results presented by Kim et al. (2009). Mineral dust aerosol are observed from the surface to 1.5 or $2 \mathrm{~km}$ of altitude in Banizoumbou during January and are associated with airmass originating in the Sahara region, while at altitudes between $2-5 \mathrm{~km}$ winds from south or south-east brought biomass burning aerosol loaded air masses from the source regions to the Sahel.

It is possible that our reduced time coverage during the dry season - profiles at the end of February - is mainly in- fluenced by local sources that are not observed by ATSR and thus is poorly representative for the average 2006 dry season condition. This point will be further discussed when presenting the CALIOP analysis.

During the summer season trajectories between 0 and $2 \mathrm{~km}$ of altitude (lower left panel) show two main pathways: monsoon circulation transport air from the Guinea Gulf, concurrently with a flow from Northern Africa related to the heatlow induced circulation. Both pathways are linked to observations discussed here which show little or no presence of biomass aerosol. Hence, the analysis of 2006 lidar observations does not provide any evidence of the cross equatorial transport of BBA due to the extensive biomass burning occurring in the southern part of Africa at that time of the year reported by Real et al. (2010) and Barret et al. (2008) in the mid-troposphere.

Back-trajectories analyses for 2006 revealed that air masses at the two upper levels originated mainly in the Northern and North-Eastern Africa. The majority of observations can be interpreted as DD, sometimes in very intense events, being well in accordance with the mentioned air mass transport pathway.

Trajectory analysis also shows that BBA which have been occasionally observed at our measurements sites, could originate from sparse fires in Northern Africa.

Back-trajectories arriving in Cinzana station show strong similarity with the back-trajectories obtained for the Banizoumbou site (Fig. 2) and, hence, are not presented here. 
During the dry season the air masses at low levels (up to $2 \mathrm{~km}$ of altitude) originate in the North of the Sahara desert and at the Atlantic Ocean (upper left panel) while between 2 and $6 \mathrm{~km}$ of altitude, the transport is mainly zonal, crossing biomass burning sources (upper central panel) in fair agreement with observations that shows the presence of BBA in layers between 2 and $5 \mathrm{~km}$ of altitude.

During the wet season the trajectories of air masses below $2 \mathrm{~km}$ of altitude show a monsoon circulation from the Guinea Gulf and a zonal flow nearby the measurement site which can be connected with observations showing that BBA are rarely present.

In the upper layers $(2-6 \mathrm{~km})$ air masses come mainly from the Northern and North-Eastern Africa and the observations can be interpreted as DD.

\section{Inter-annual variability}

The inter-annual pattern of aerosol variability during the years 2006, 2007 and 2008 was studied by inspecting the AOD and Ångström coefficient time series provided by the AERONET sunphotometer stations in Dakar (approximately $80 \mathrm{~km}$ north of M'Bour), Senegal, Cinzana and Banizoumbou, as well as through investigation of the total attenuated backscattering provided by the CALIOP lidar. For the sake of clarity, and for direct comparison with the ground based data, we denoted these regions as M'Bour, Cinzana and, Banizoumbou for the westmost, central and eastmost region respectively. When comparing ground based with the satellite observations, one should bear in mind that the latter are in fact average values in the $11^{\circ} \mathrm{N}-15^{\circ} \mathrm{N}$ latitudinal band, grouped into longitudinal regions over, $15^{\circ} \mathrm{W}-20^{\circ} \mathrm{W}, 5^{\circ} \mathrm{W}-$ $10^{\circ} \mathrm{W}$ and $0^{\circ} \mathrm{E}-5^{\circ} \mathrm{E}$.

The profiles have been averaged over the 20 CALIOP retrievals nearest to the selected locations, which corresponds to an horizontal coverage of approximately $6.6 \mathrm{~km}$.

Three years of time series of attenuated aerosol backscattering profiles (row a) obtained by AERONET sunphotometers for Banizoumbou region are given in Fig. 3. Figures 5 and 7 show similar results for the Cinzana and the MBour region, respectively.

A cloud mask has been applied to the CALIOP dataset to remove possible contributions from low level clouds, which appear in the plots as white zones.

In the three figures, the Sahelian region is characterized by a large day to day variability, above all during summer season. This can be attributed to scavenging processes during intense raining events.

\subsection{Banizoumbou region $\left(11^{\circ}-15^{\circ} \mathrm{N} ; 0^{\circ}-5^{\circ} \mathrm{E}\right)$}

A common seasonal pattern is discernible in Banizoumbou, in the total attenuated backscattering profiles (Fig. 3a) showing for 2007 and 2008 an aerosol burden starting at the lowermost levels (below $2 \mathrm{~km}$ ) in January, slightly reducing in February then steadily increasing from mid February to March. In that period, the aerosol burden between the ground and $2 \mathrm{~km}$ is highest in 2007. The aerosol burden increases in vertical extension and intensity expanding up to $4-5 \mathrm{~km}$ of altitude in April and the aerosol backscattering reaches the largest values between mid May and July when the monsoon activity induces a progressive clearing up of the atmosphere at the lowermost levels. At the end of the summer season the backscattering begins to taper off reducing its vertical extension and intensity until December, when it reaches the low winter values.

A clear seasonal pattern is evident in the AOD in row (b) in Fig. 3, showing an increase in AOD values from January to September with maxima higher than 1 ( up to 2.5-3 in 2007 and up to 2 in 2006 and 2008) in intense events in spring (March-April) and in summer (June-July). Then it reduces to values lower than 1 in the last part of the year above all in 2006 even if sporadic events with AOD greater than 1 up to 2 are observed in 2006 and 2008

The inter-annual variation is limited. In the period January-February and June-July, the year 2007 shows larger AOD values with respect to the values in the other years.

The Ångström coefficient shown in row (c) of Fig. 3 attains its higher values than those in the other years. (in January-February, between 0.5 and 1 in 2006 and around 0.5 in 2007 and 2008), during July and August (sporadically up to 1.5 in 2006 and 2008 and more often in 2007), and in December (greater than 1). It is often correlated with low AOD values, thus indicating the presence of smaller particles, which, according to the classification depicted in Table 1 , can be attributed to the presence of BBA.

In the rest of the year, A stays below 0.5 in correspondence with larger AOD values, indicating that dust particles, associated with the Saharan air masses, are then the dominant contributor to the AOD.

The limited interannual variability allows to evaluate the average seasonal evolution of aerosol based on the depolarization $\mathrm{D}$ and the color index $\mathrm{C}$ derived from CALIOP measurements.

In Fig. 4 the joint probability density function (PDF) for $\mathrm{D}$ and $\mathrm{C}$ retrievals for different seasons depicted in four consecutive columns as January-February (JF), MarchApril-May (MAM), June-July-August-September (JJAS), October-November-December (OND) for two atmospheric layers, the lower one up to $2 \mathrm{~km}$ (row a) and a high layer between 2 and $6 \mathrm{~km}$ (row b) with the lower layer being representative for the boundary layer and the higher corresponding with the free troposphere.

Each PDF is normalized for the number observations and is expressed in arbitrary units.

Observations with high $\mathrm{D}$ and land low $\mathrm{C}$ represent DD aerosol while low D and high $\mathrm{C}$ correspond with BBA. Intermediate optical parameters indicate a mixture of different aerosols. 
a)
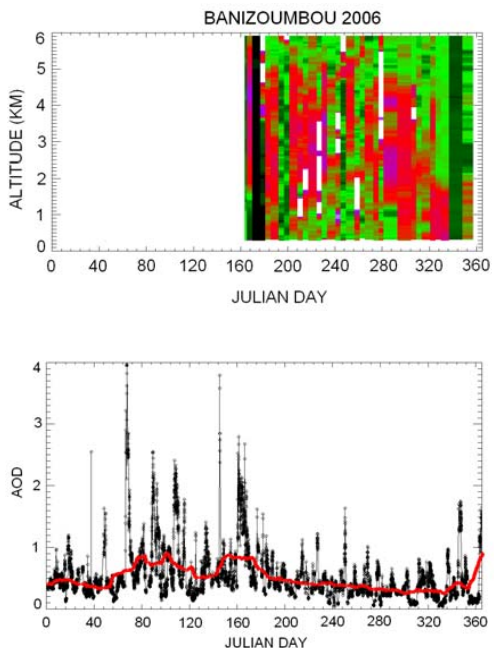

c)

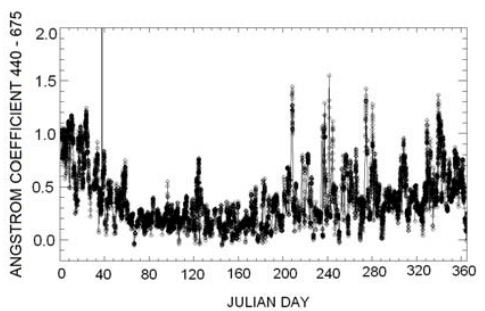

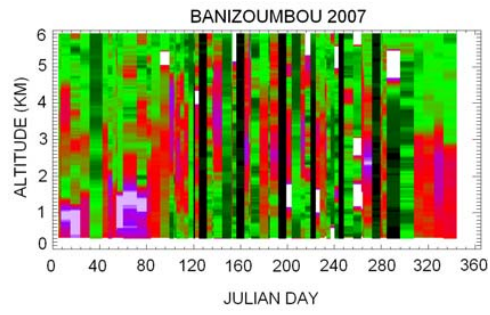
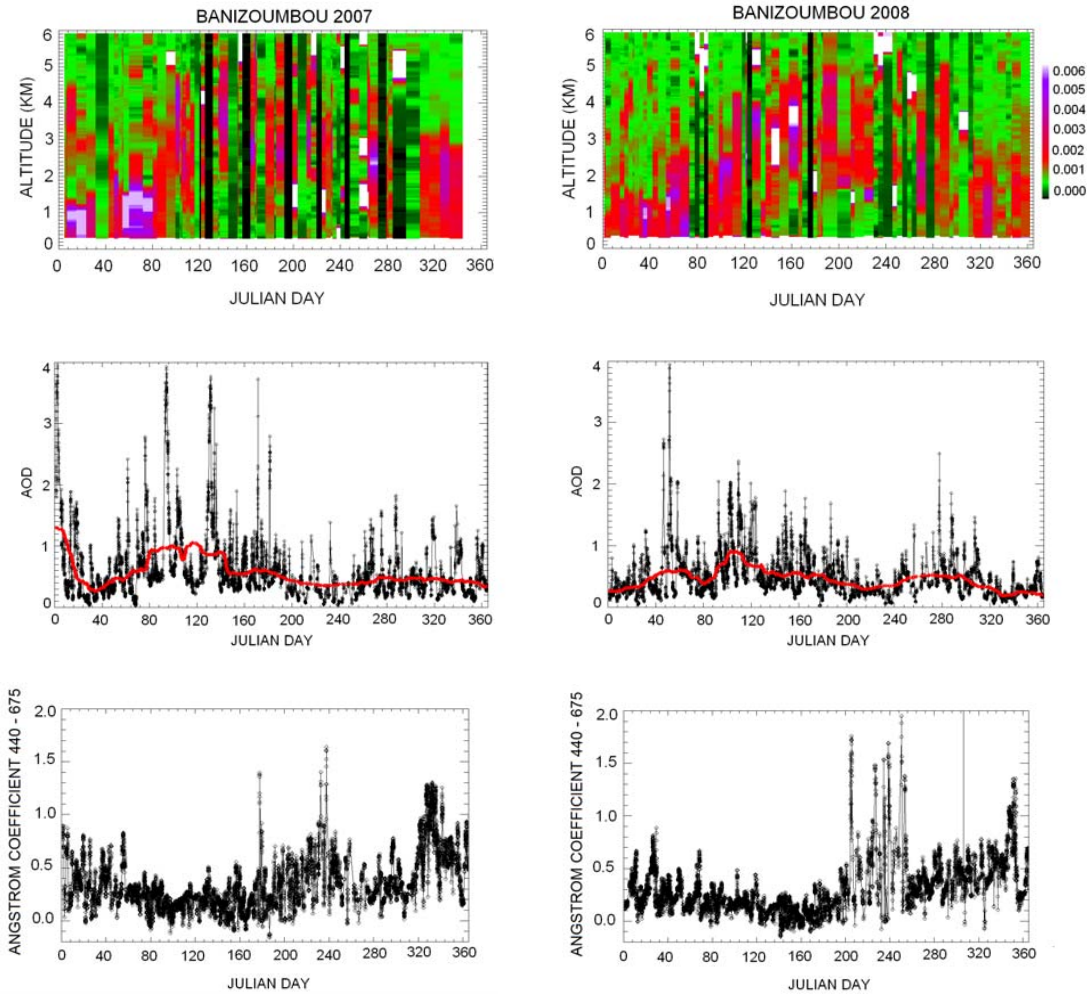

Fig. 3. The total attenuated backscatter $\left(\mathrm{km}^{-1} \mathrm{sr}^{-1}\right)$ obtained at $532 \mathrm{~nm}$ from CALIPSO database (row a) along with time series of aerosol optical depth (row b) and Ångström coefficient (row c) estimated at $532 \mathrm{~nm}$ from AERONET database for year 2006 (left), 2007 (middle) and 2008 (right) at Banizoumbou site. The red line in (row b) represents represent a one-month running average of the AOD time series.
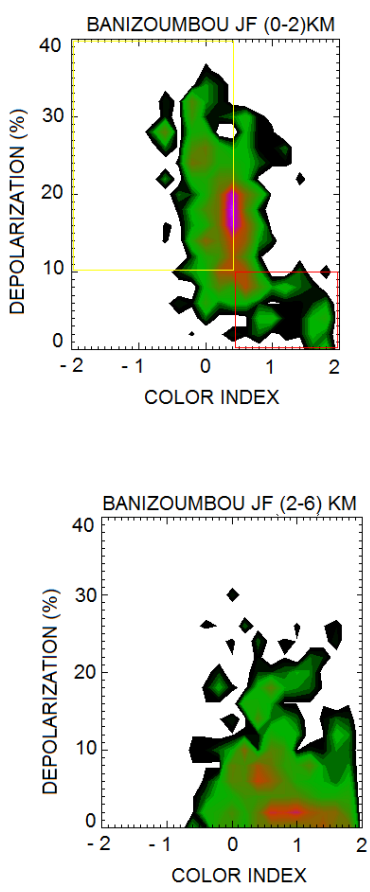
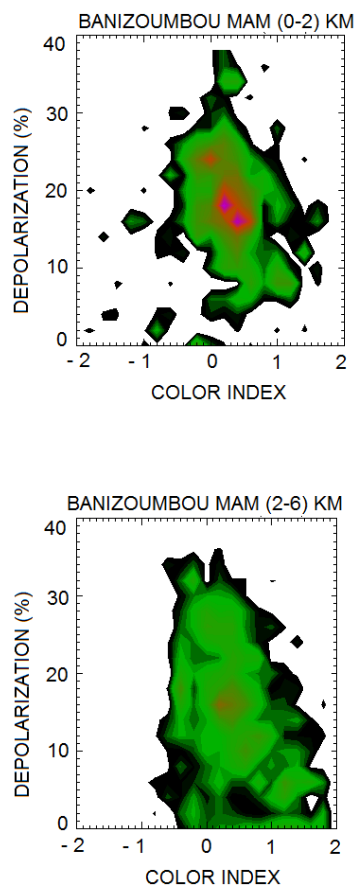
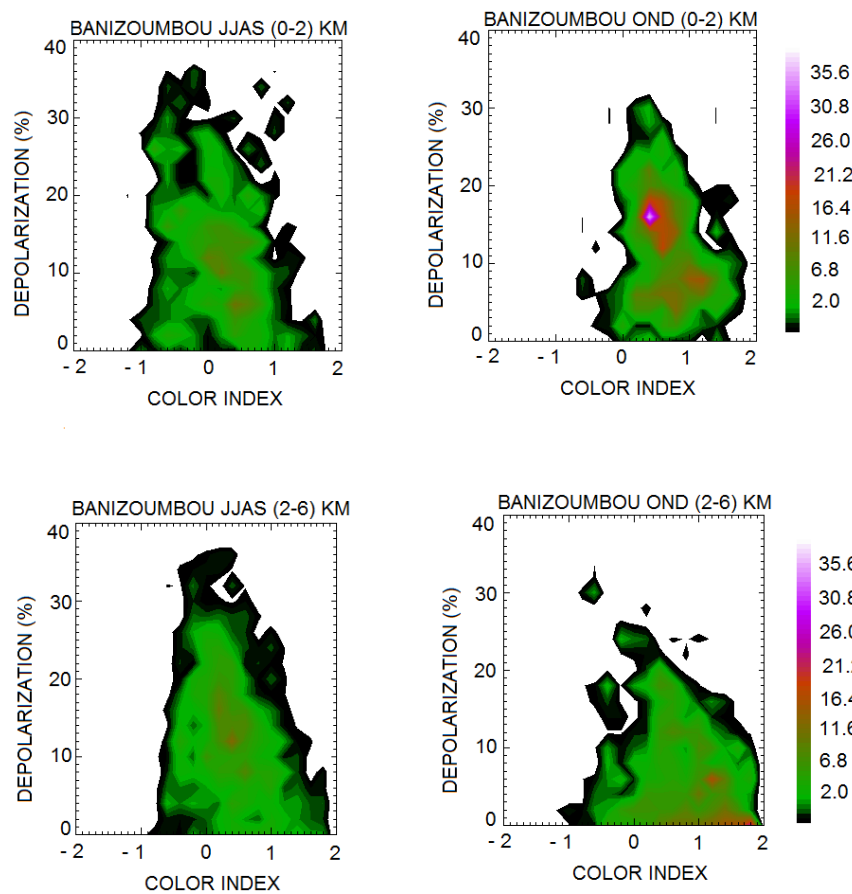

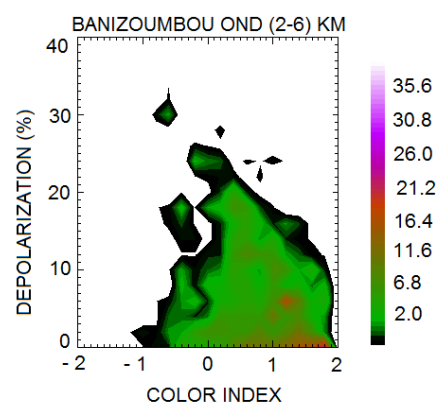

Fig. 4. Joint PDF for Color Index and Depolarization retrieved from CALIOP observations for different seasons over the Banizoumbou site. Column 1-4 show the data for the months January-February (JF), March-April-May (MAM), June-July-August-September (JJAS) and October-November-December (OND), respectively. The upper row shows results for the boundary layer (0-2) km while the lower row corresponds with the troposphere (2-6) km. Using the criteria specified in Table 4, in the upper left subplot yellow and red rectangles identify, respectively, desert dust and biomass burning aerosols. The same rectangles also apply to the other panels. 

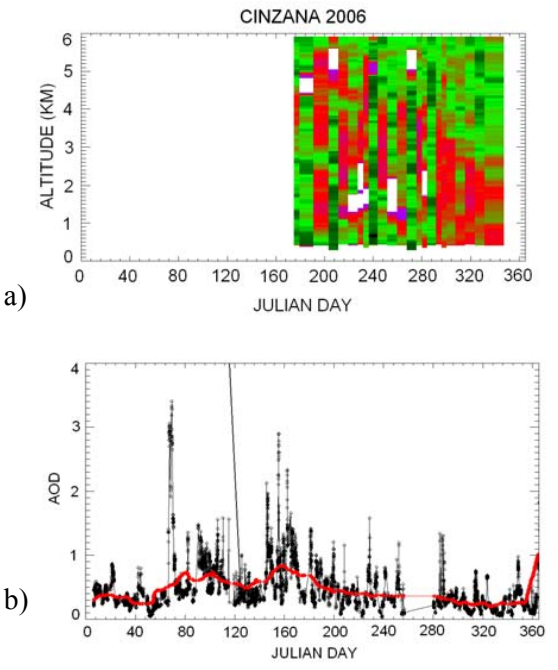

c)

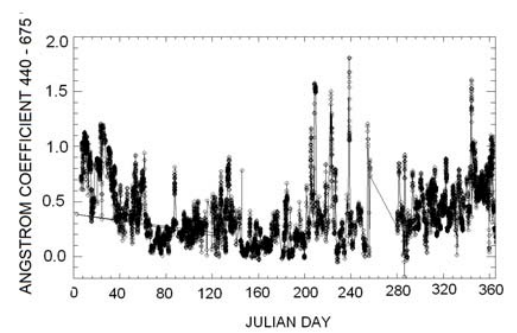

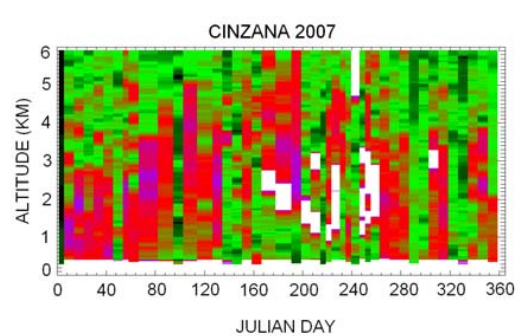
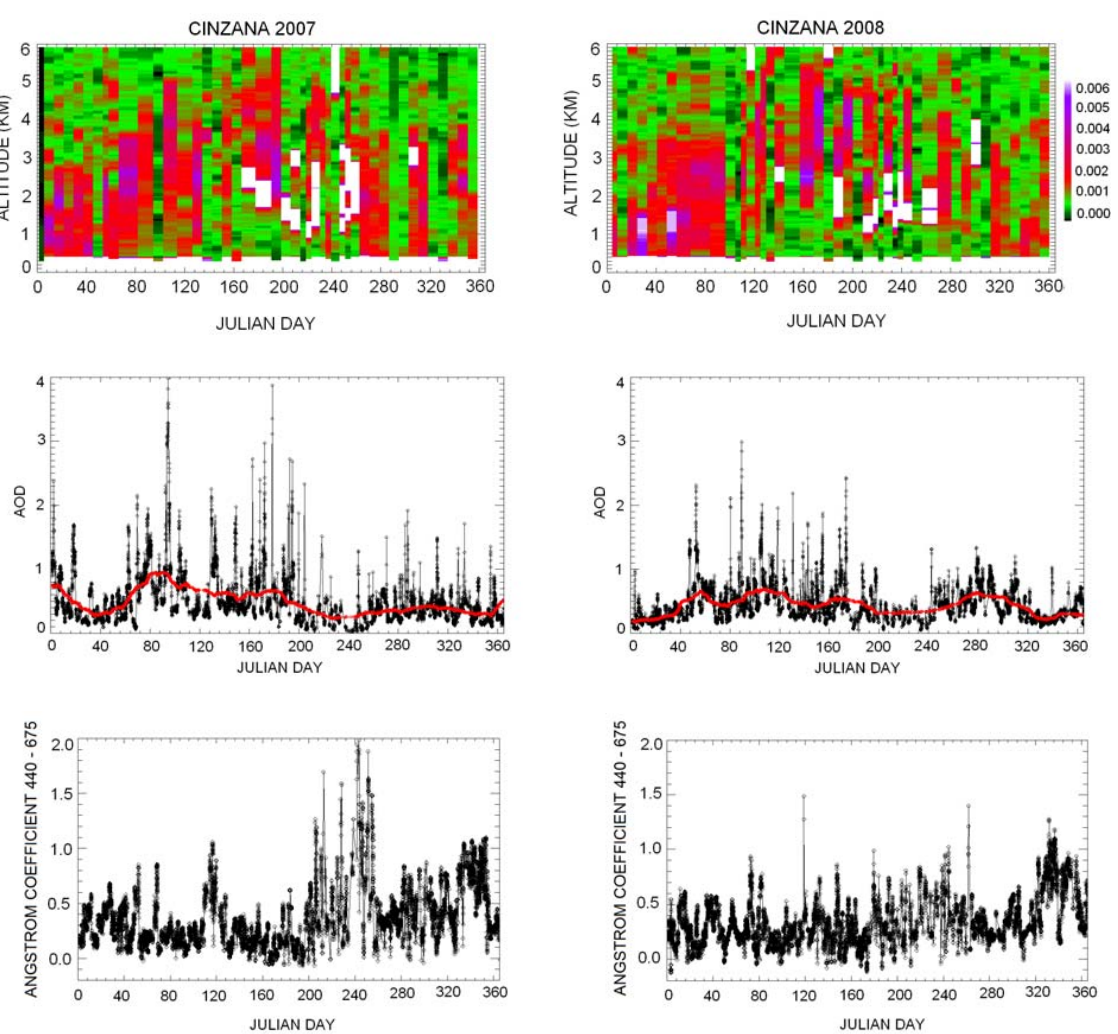

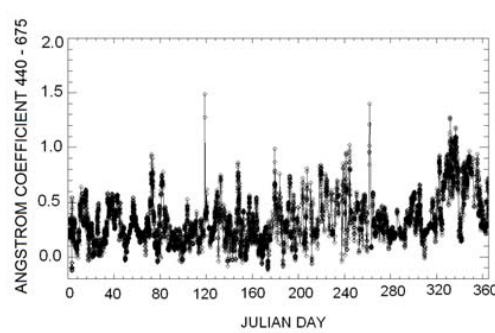

Fig. 5. Total attenuated backscatter $\left(\mathrm{km}^{-1} \mathrm{sr}^{-1}\right)$ obtained at $532 \mathrm{~nm}$ from CALIPSO database (row a) along with time series of aerosol optical depth (row b) and Ångström coefficient (row c) estimated at $532 \mathrm{~nm}$ from AERONET database for year 2006 (left), 2007 (middle) and 2008 (right) at Cinzana site. The red line in (row b) represents a one-month running average of the AOD time series.

For the dry season (JF in Fig. 4) a clear difference in particle optical properties is evident between the low and the high layer. The most frequent observations in the elevated layer are for particles with typical optical values for BBA, while the lower layer has frequent observations of DD. Both DD and BBA show a compact distribution in the $(\mathrm{C}, \mathrm{D})$ space indicating, on a qualitative basis, that the two layers appear to be well separated.

During MAM an increase of high D observations in the upper layer suggests an increasing presence of DD with lower values of PDF than in the lower layer. During the summer season (JJAS), DD observations are dominating in both layers, although a significant presence of BBA indicates clearly the observation of mixed states that are more pronounced in this season.

During fall (OND) DD observations are more probable than BBA in the lower layer while the presence of BBA is predominant in the upper one.

\subsection{Cinzana region $\left(11^{\circ}-15^{\circ} \mathrm{N}, 5^{\circ} \mathrm{W}-10^{\circ} \mathrm{W}\right)$}

The seasonal pattern of the aerosol vertical distribution obtained for the Cinzana region is similar to that observed in Banizoumbou. The CALIOP observations (Fig. 5a), show presence of aerosol up to $3 \mathrm{~km}$ of altitude at the beginning of the year (January-February) in 2007 and 2008, increasing in intensity and vertical extension up to $4-5 \mathrm{~km}$ at the beginning of the spring season, reaching maximum values in summer (June-July). The year 2008 is characterized by a higher aerosol content below $2 \mathrm{~km}$ at the end of January and at mid February, with respect to 2007. A larger aerosol presence is also discernible at the end of 2006 with respect to other sites.

The bulk of the aerosol vertical distribution follows the similar seasonal pattern observed over Banizoumbou. However for the Banizoumbou site, AOD values (Fig. 5b) are higher in the first part of the year (from January to September) compared to the end of the year with maximum values in spring and in summer.

In the period January-February and around mid July, the year 2007 is characterized by larger AOD values, between 0.5 and 1.5, with respect to the year 2006 .

The Ångström coefficient A (Fig. 5c) is lower than 0.5 in spring, except for a peak $(>0.5)$ in April; in summer (from mid July until mid September) its values exceed 1.5, while in the last part of the year, from the end of October to December, values around 1 have been found.

Again these large values of A are often in correspondence of low AOD values (or the other way around), suggesting the presence of BBA (or DD). 

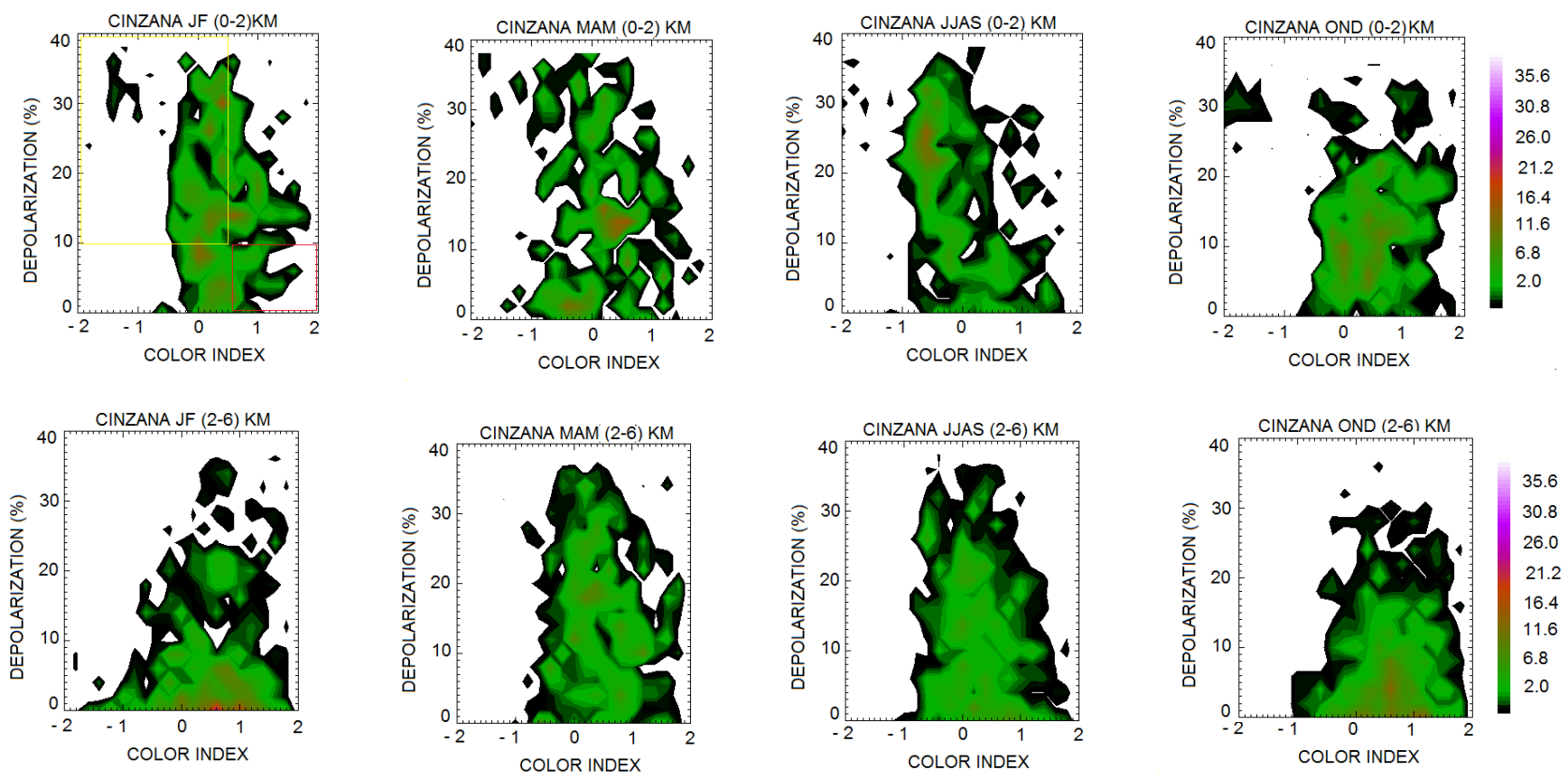

Fig. 6. Joint PDF for Color Index and Depolarization retrieved from CALIOP observations for different seasons over the Cinzana site. Column 1-4 show the data for the months January-February (JF), March-April-May (MAM), June-July-August-September (JJAS) and October-November-December (OND), respectively. The upper row shows results for the boundary layer (0-2) km while the lower row corresponds with the troposphere (2-6) km. Using the criteria specified in Table 4, in the upper left subplot yellow and red rectangles identify, respectively, desert dust and biomass burning aerosols. The same rectangles also apply to the other panels.

Weak year-to year difference is mainly confined to the dry season and summer onset: at the beginning of the year, 2006 is characterized by larger A values, even above 1 while in June-July of 2006 and 2007 A values even beyond 1.5 while in 2008 they remain below 1 . The joint probability density function for CALIOP's D and C over Cinzana region is depicted in Fig. 6. The difference of particle population between the layers is less evident with respect to Banizoumbou. The increase of high D observations in the upper layer of the atmosphere observed in MAM, indicative of an increasing presence of DD, is however still evident at this location.

\subsection{M'Bour region $\left(11^{\circ}-15^{\circ} \mathrm{N}, 1^{\circ} \mathrm{W}-20^{\circ} \mathrm{W}\right)$}

Figure 7a depicts clear annual aerosol evolution over M'Bour.

The bulk of the of aerosol vertical distribution is located around $3 \mathrm{~km}$ of altitude throughout the year and its behaviour shows a less pronounced (with respect to Banizoumbou and Cinzana) seasonal variability of the vertical distribution with maxima in March and at mid July, when the AOD reaches values up to 2.5 (in 2006).

The AOD values (Fig. 7b) are most of the time below 0.5 during the dry season and between the end of October and December while AOD average values less than 1 are present during the summer season and and are generally lower than in the other two sites throughout the year.
The behaviour of the A coefficient is also qualitatively similar to the two inland sites with increased values during the winter and sporadic maxima during the summer season but the values of A during BBA episodes in summer are smaller than in Banizoumbou and Cinzana. Again the main features of the annual cycle show weak variability on the year-to-year scale. However the year 2006 is characterized by larger A values during the dry season, suggesting more frequent observations of BBA.

Figure 8 shows the joint probability density function for CALIOP D and Color Index. The behavior of the PDF in the upper and lower layers is different from what has been observed in Banizoumbou in the sense that the clearly discernible difference of particle population between the high and low layers is still visible in winter (JF) and in fall (OND).

Finally, a noticeable presence of absorbing aerosol $(C<0)$ is observed in winter (JF) in the upper layers.

\section{Back-trajectory analysis}

In order to evaluate the role of transport on the vertical and temporal variability of the aerosol discussed above, the number of back-trajectories encountering potential aerosol sources and ending in the three sites is estimated as a function of time and height. 
a)

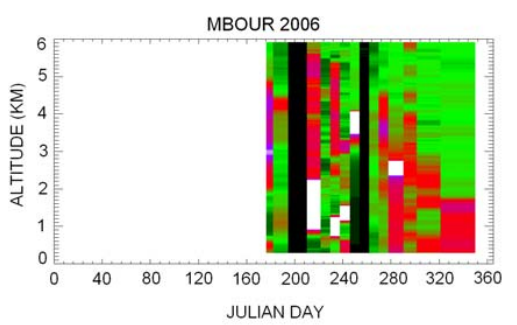

b)

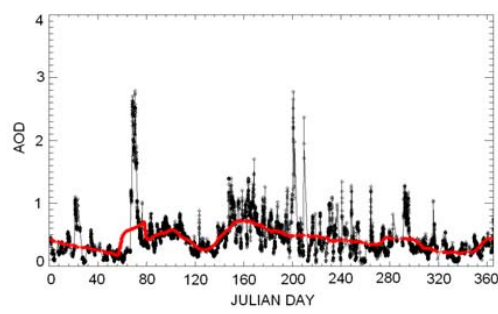

c)

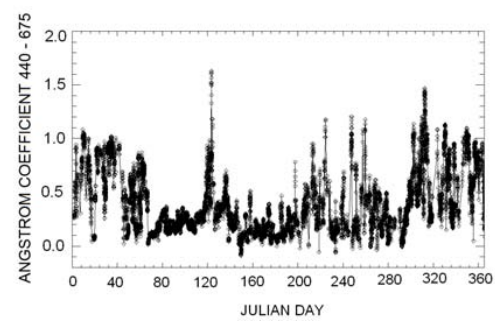

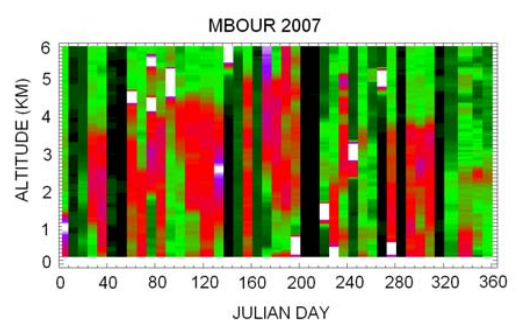
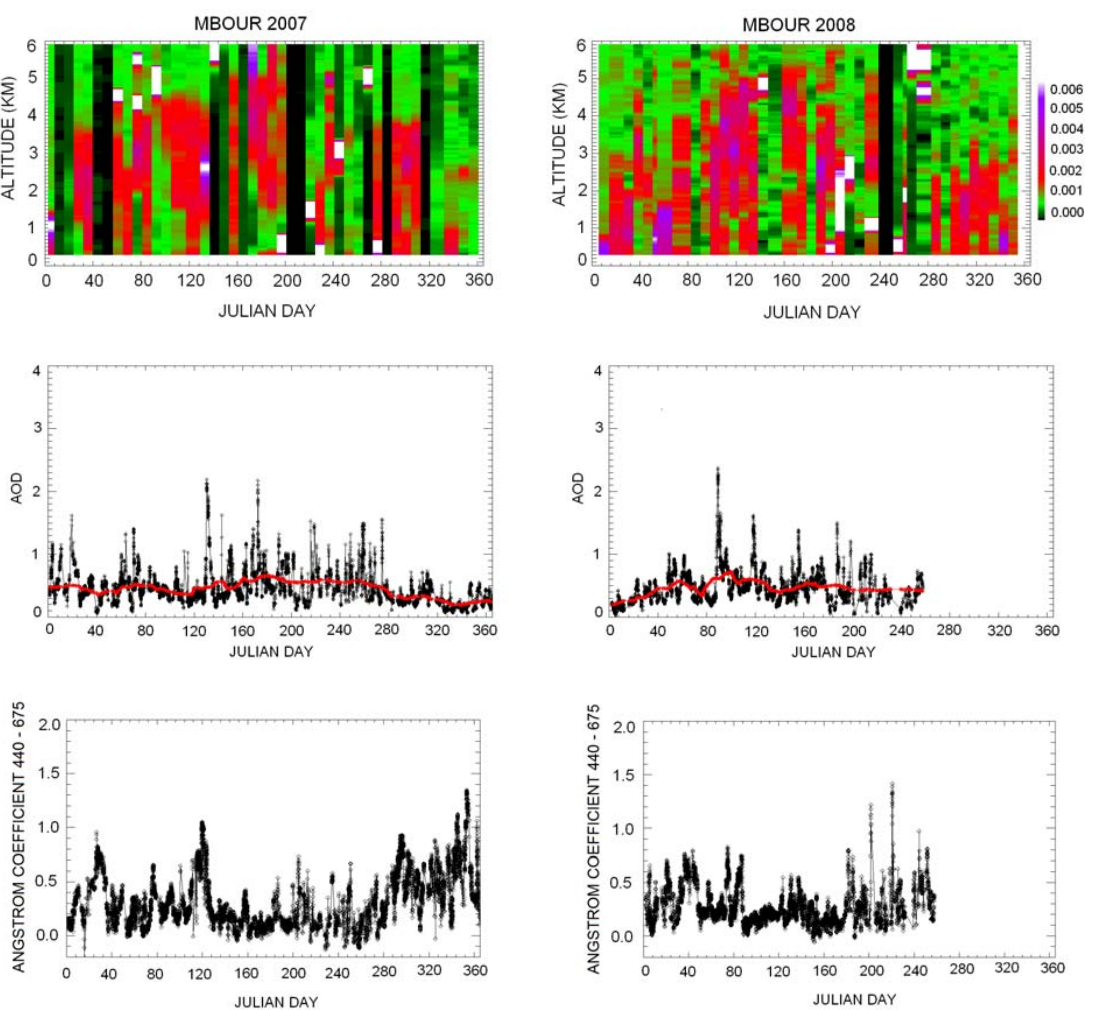

Fig. 7. Total attenuated backscatter $\left(\mathrm{km}^{-1} \mathrm{sr}^{-1}\right)$ obtained at $532 \mathrm{~nm}$ from CALIPSO database (row a) along with time series of aerosol optical depth (row b) and Ångström coefficient (row c) estimated at $532 \mathrm{~nm}$ from AERONET database for year 2006 (left), 2007 (middle) and 2008 (right) at Dakar site. The red line in (row b) represents a one-month running average of the AOD time series.

Figure 9 depicts the average position of air masses 4 to 6 days before their arrival at Banizoumbou at $500 \mathrm{hPa}$, for the period January-February-March (JFM) 2006.

Trajectories have been calculated on a daily basis at different pressure levels, as described in Sect. 2. In order to identify potential dust emissions, the desert region is indicated with a blue box and to identify air masses transported by the monsoon flow, the Guinea Gulf is enclosed in a yellow box. A red solid contour encompasses the regions where forest fires observed by AATSR occurred.

The superposition of the back-trajectories and the BBA sources indicates that in winter at the $500 \mathrm{hPa}$ level air masses came preferentially from regions with BBA emission, rather than from the desert region due to a northward transport from Equatorial Africa which was inhibited by the winter circulation (Fig. 10a).

Such plots have also been produced for Cinzana and M'Bour for all seasons and all years, and are available in the Supplement associated with this article.

Figure 10 summarizes the variability of back-trajectories, showing the time-height evolution of air masses encountering the Desert region (blue) transported by the Monsoon flow (orange) and encountering biomass burning (red) for three sites (columns) and 2006-2008 years (rows).
A remarkably similar pattern of air masses origin is present throughout the three years study, and in common to the three sites.

Air from the Sahara desert is present throughout the year. It is observed in the lower layers at the beginning and end of the year, and extending upward during the middle of the year. At that time, the lower layers are less affected by influence from the Sahara when the monsoon flow carries inland air from the Guinea Gulf and the Southern Hemisphere. The biomass burning influence (red) is mainly confined in the higher layers, observable at the beginning and at the end of the year, although sparse events might still be discerned throughout the year. Noteworthy, the desert influence is remarkably similar in the three sites for the second part of the year, while during spring, it decreases westward from Banizoumbou to M'Bour.

Noticeable is also an absence of the BBA similar for the three sites; for julian days 200-270 at Banizoumbou, 190-270 at Cinzana and 180-280 at M'Bour due to the establishment, during the summer season, of a circulation mainly from the Guinea Gulf in the lower layers and from the Sahara desert in the upper layers where the biomass burning sources are strongly reduced. 

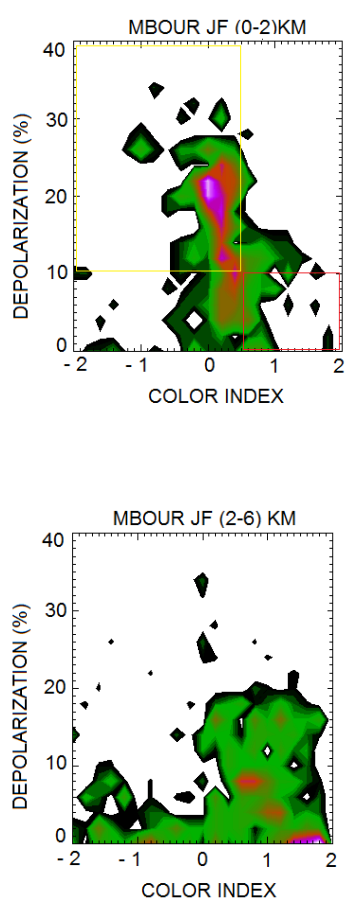
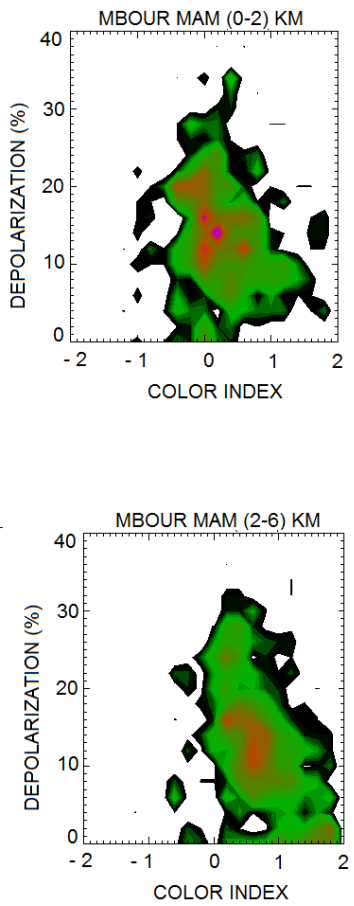
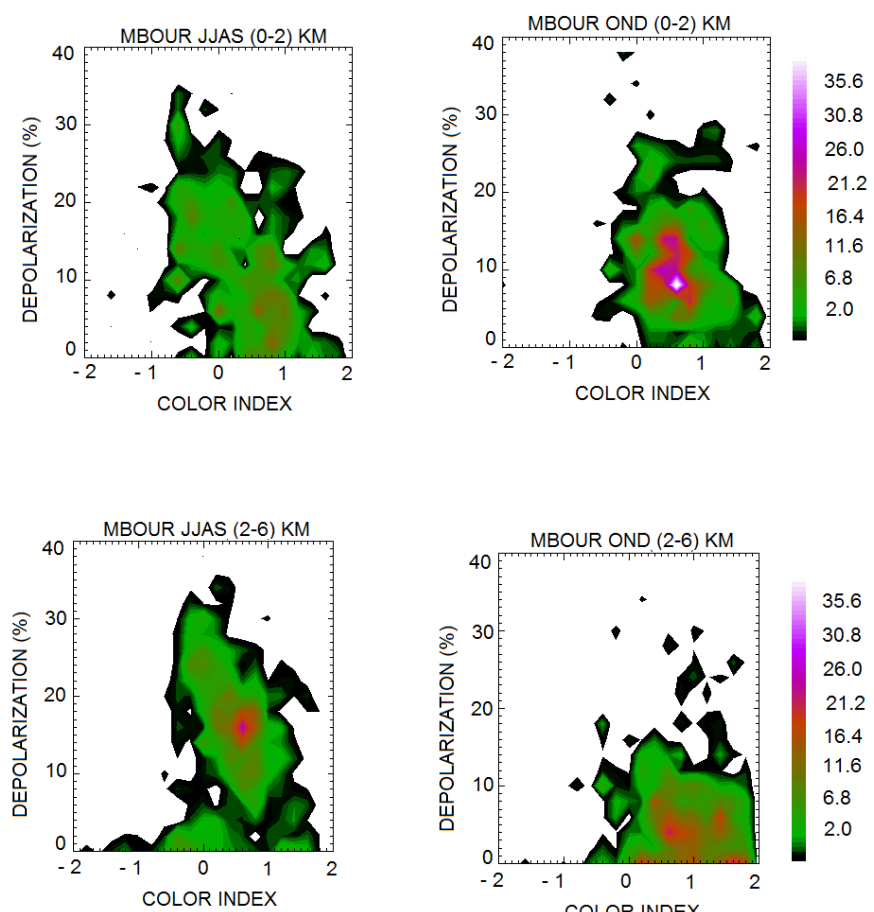

Fig. 8. Joint PDF for Color Index and Depolarization retrieved from CALIOP observations for different seasons over the M'Bour site. Column 1-4 show the data for the months January-February (JF), March-April-May (MAM), June-July-August-September (JJAS) and October-November-December (OND), respectively. The upper row shows results for the boundary layer (0-2) km while the lower row corresponds with the troposphere (2-6) km. Using the criteria specified in Table 4, in the upper left subplot yellow and red rectangles identify, respectively, desert dust and biomass burning aerosols. The same rectangles also apply to the other panels.

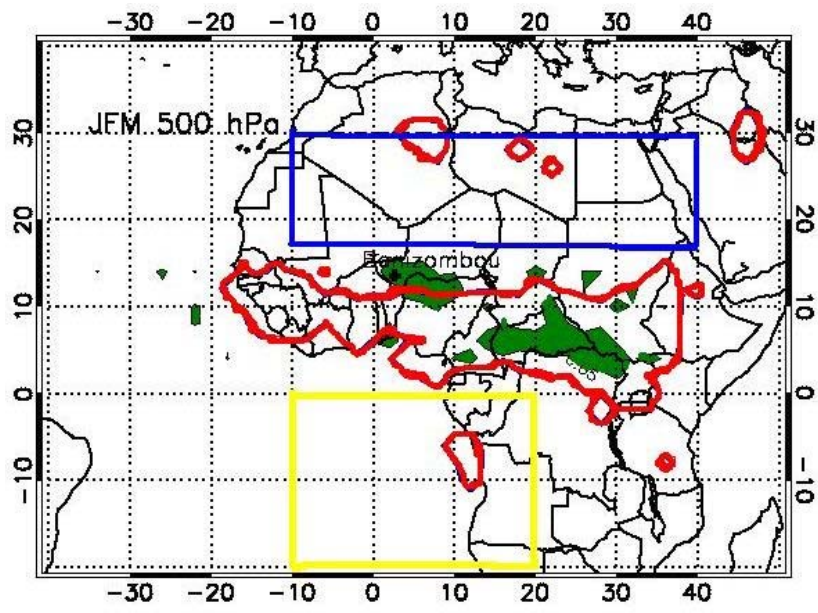

Fig. 9. Number of trajectories per day averaged in JanuaryFebruary-March (JFM) 2006. Trajectories are binned in a $2^{\circ}$ latitude-longitude grid. Red contours indicate the average position 4 to 6 days before arrival at $500 \mathrm{hPa}$ over Banizoumbou. Red contours indicate areas where forest fires observed from AATSR occur. Fire pixel have been taken into account whenever their number is larger than 10 in the three months period Areas defined as "Desert" and "Ocean" are indicated by blue and yellow rectangles, respectively.
Figure 10 does not show a large inter-annual variability of the air masses circulation over the three sites ; the main differences are observed over the Cinzana site in summer 2007 when the monsoon flow from the Guinea Gulf is almost absent in the lower layers of the atmosphere if compared to the other years, and during the dry season 2008 over both Banizoumbou and over the Cinzana site when the layers above $3 \mathrm{~km}$ of altitude are less affected by air masses influenced by biomass burning.

The seasonal pattern of air mass influences and the main difference in the air mass circulation are confirmed by AOD and A time series analysis shown in Figs. 3, 5 and 7 for the three sites over the three years.

\section{Summary and conclusions}

In this work, we have studied the seasonal and inter-annual variability of the aerosol vertical distribution over three years in the Sahel region, characterizing the different type of aerosols present in the atmosphere in terms of their optical properties observed by ground-based and satellite instruments, as well as in terms of their sources obtained using back-trajectories. 

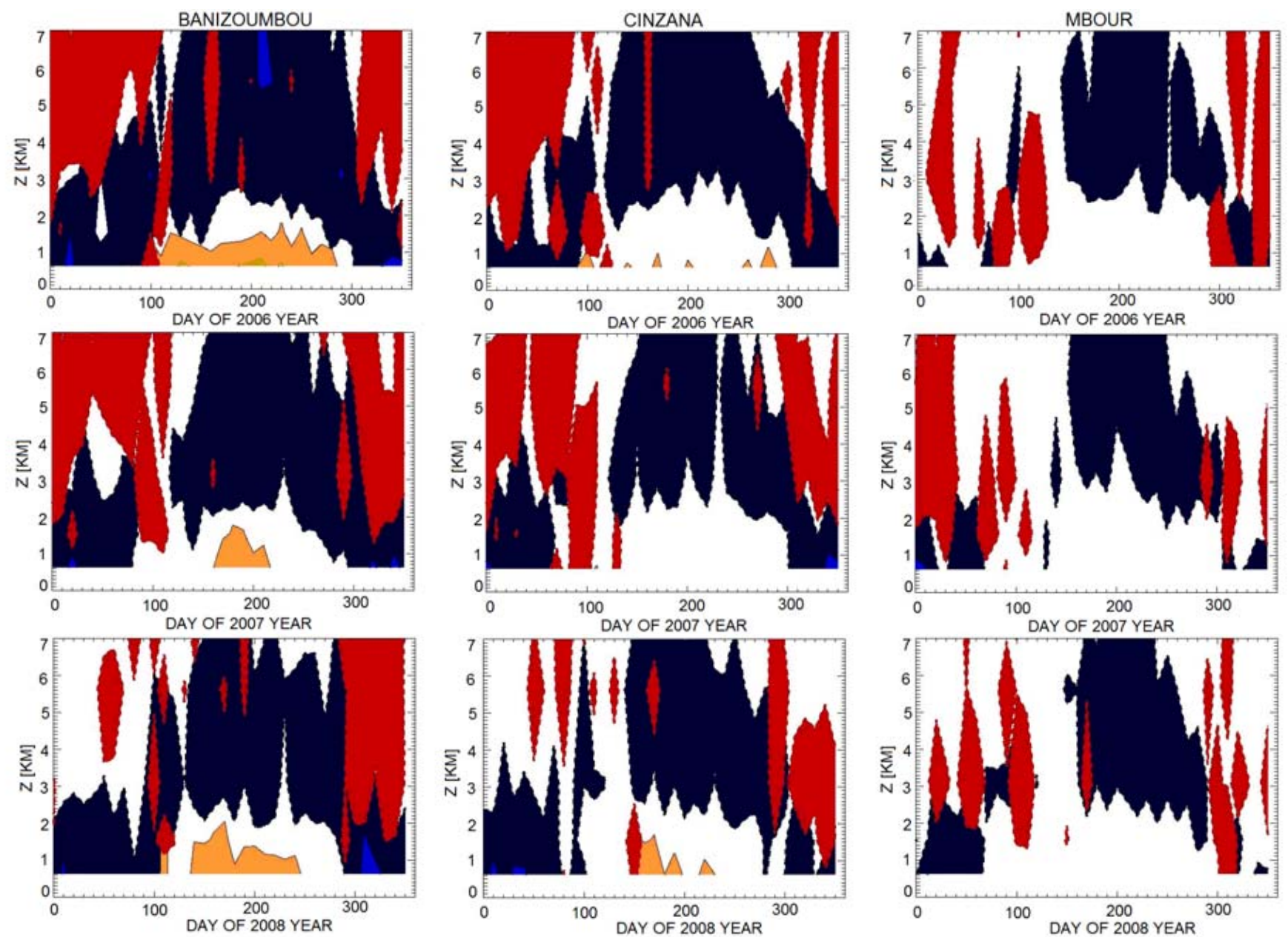

Fig. 10. Time-height evolution for air masses originating in the Desert region (blue) and the Ocean region (orange) as well as the air masses encountering Forest fires observed by AATSR (red). Number of trajectories is averaged over 10 days. Units are arbitrary.

During winter, the lower level air masses arriving in the Sahelian region come mainly from North, North-West and from the Atlantic area, while in the upper troposphere air flows generally originate from West Africa, crossing a region characterized by the presence of large biomass burning sources. The sites of Cinzana, Banizoumbou and M'Bour, along a transect of aerosol transport from East to West, are in fact under the influence of tropical biomass burning aerosol emission during the dry season, as revealed by the seasonal pattern of the aerosol optical properties and by back-trajectory studies. There, BBA are mainly observed in January-February, confined in the upper layers of the atmosphere. This is particularly evident for year 2006, which was characterized by a large presence of biomass burning aerosols in all the three sites.

Biomass burning influenced aerosols also observed during the summer season (from July to September) transported by the monsoon flow originating in Southern Africa, a region characterized by the presence of large biomass burning sources.
Sporadic biomass burning events are also observed in spring, since in this period air masses coming from North Africa and and the Saharian desert pass over biomass burning sources placed sparsely in the tropical area.

During the summer months, the entire Sahelian area is under the influence of Saharan dust aerosols. The air masses in low levels arrive from West Africa crossing the Sahara desert or from the Southern Hemisphere crossing the Guinea Gulf. In the upper layers air masses still originate from North, North- East. In this period the maximum of the desert dust activity is observed, widespread along the entire Sahelian transect, which is characterized by large AOD and backscattering values. It also corresponds to a maximum in the extension of the aerosol vertical distribution (up to $6 \mathrm{~km}$ of altitude). In correspondence, a progressive cleaning up of the lowermost layers of the atmosphere is occurring, especially evident in Banizoumbou and Cinzana sites. 
Summer is characterized by extensive and fast convective phenomena and this is evident in the lidar profiles. They often show cases of large dust events loading the atmosphere with aerosol from the ground up to $6 \mathrm{~km}$ of altitude. These events are characterized by large total attenuated backscattering values, and alternate with very clear profiles, sometimes separated by only a few hours, indicative of fast removal processes occurring, likely due to intense convective and rain activity.

This work has provided a long-term characterization of Sahelian aerosol from a seasonal to a multi-annual timescale. Different types of aerosol have been defined accordingly to their optical characteristics. Their seasonal evolution has been tracked during three years and their sources have been identified using back-trajectories studies, which showed tracked during three years and their sources have been with what inferred from the observations.

\section{Supplementary material related to this article is available online at: http://www.atmos-chem-phys.net/10/12005/2010/ acp-10-12005-2010-supplement.pdf.}

Acknowledgements. Based on a French initiative, AMMA was built by an international scientific group and is currently funded by a large number of agencies, especially from France, the United Kingdom, the United States, and Africa. It has been the beneficiary of a major financial contribution from the European Community's Sixth Framework Research Programme. Detailed information on scientific coordination and funding is available on the AMMA International Web site at: www.amma-international.org.

The CALIPSO data were obtained from the NASA Langley Research Center Atmospheric Science Data Center (ASDC) via online web orders. We are grateful to the entire CALIPSO and ATSR science team for providing the data.

This work has benefited of the logistical support of SRAC/IER (Station de Recherche Agronomique de Cinzana/Institut d'Economie Rurale) in Mali and of the African delegations of IRD (Institut de Recherches pour le Développement) in Mali, Sénégal and Niger.

The authors are very thankful to the local site operators in Niger (A. Maman, A. Zakou), Mali (M. Coulibaly, I. Koné) and Sénégal (A. Diallo, T. NDiaye) for their technical help in maintaining the lidars and the sun photometers. We thank too the PHOTONS and AERONET teams for managing the sun photometer network and providing high quality data.

Edited by: M. C. Facchini

\section{References}

Alpert, P., Neeman, B. U., and Shay-el, Y.: Climatological analysis of Mediterranean cyclones using ECMWF data. Tellus 42A, 6577, 1990.

Ångström, A. : The parameters of atmospheric turbidity, Tellus, 16, 64-75, 1964.
Ansmann A., Bösenberg, J., Chaikovsky, A., Comerón, A., Eckhardt, S., Eixmann, R., Freudenthaler, V., Ginoux, P., Komguem, L., Linné H., López Márquez, M. A., Matthias, V., Mattis, I., Mitev, V., Müller, D., Music, S., Nickovic, S., Pelon, J., Sauvage, L., Sobolewsky, P., Srivastava, M. K., Stohl, A., Torres, O., Vaughan, G., Wandinger, U., and Wiegner, M.: Long-range transport of Saharan dust to northern Europe: The 11-16 October 2001 outbreak observed with EARLINET ,J. Geophys. Res., 108(D24), 4783, doi:10.1029/2003JD003757, 2003.

Arino, O. and Plummer, S. (Eds.): Along Track Scanning Radiometer World Fire Atlas: validation of the 1997-1998 active fire product, Validation report, IGBP-DIS Working Pap. 23, Int. Geosph. Biosph. Progr., Stockholm, 2001.

Balis, D. S., Amiridis, V., Nickovic, S., Papayannis, A., and Zerefos, C.: Optical properties of Saharan dust layers as detected by a Raman lidar at Thessaloniki, Greece, Geophys. Res. Lett., 31, L13104, doi:10.1029/2004GL019881.c, 2004.

Barret, B., Ricaud, P., Mari, C., Attié, J.-L., Bousserez, N., Josse, B., Le Flochmoën, E., Livesey, N. J., Massart, S., Peuch, V.H., Piacentini, A., Sauvage, B., Thouret, V., and Cammas, J.P.: Transport pathways of $\mathrm{CO}$ in the African upper troposphere during the monsoon season: a study based upon the assimilation of spaceborne observations, Atmos. Chem. Phys., 8, 3231-3246, doi:10.5194/acp-8-3231-2008, 2008.

Cairo, F., Di Donfrancesco, G., Adriani, A., Pulvirenti, L., and Fierli, F.: Comparison of various linear depolarization parameters measured by lidar, Appl. Optics, 38, 4425-4432, 1999.

Cairo, F., Pommereau, J. P., Law, K. S., Schlager, H., Garnier, A., Fierli, F., Ern, M., Streibel, M., Arabas, S., Borrmann, S., Berthelier, J. J., Blom, C., Christensen, T., D’Amato, F., Di Donfrancesco, G., Deshler, T., Diedhiou, A., Durry, G., Engelsen, O., Goutail, F., Harris, N. R. P., Kerstel, E. R. T., Khaykin, S., Konopka, P., Kylling, A., Larsen, N., Lebel, T., Liu, X., MacKenzie, A. R., Nielsen, J., Oulanowski, A., Parker, D. J., Pelon, J., Polcher, J., Pyle, J. A., Ravegnani, F., Rivière, E. D., Robinson, A. D., Röckmann, T., Schiller, C., Simões, F., Stefanutti, L., Stroh, F., Some, L., Siegmund, P., Sitnikov, N., Vernier, J. P., Volk, C. M., Voigt, C., von Hobe, M., Viciani, S., and Yushkov, V.: An introduction to the SCOUT-AMMA stratospheric aircraft, balloons and sondes campaign in West Africa, August 2006: rationale and roadmap, Atmos. Chem. Phys., 10, 2237-2256, doi:10.5194/acp-10-2237-2010, 2010.

Cattrall, A., Reagan, J., Thome, K., and Dubovik, O.: Variability of aerosol and spectral lidar and backscatter and extinction ratios of key aerosol types derived from selected Aerosol Robotic Network locations, J. Geophys. Res., 110, D10S11, doi:10.1029/2004JD005124, 2005.

Cavalieri, O., Di Donfrancesco, G., Cairo, F., Fierli, F., Snels, M., Viterbini, M., Cardillo, F., Chatenet, B., Formenti, P., Marticorena, B. and Rajot, J. L.: The AMMA mulid network for aerosol characterization in West Africa, Int. J. Remote Sens., doi:10.1080/01431161.2010.502156, in press, 2011.

Dayan, U., Heffter, J., Miller, J., and Gutman, G.: Dust intrusion events into the Mediterranean basin, J. Appl. Meteorol., 30, 1185-1198, 1991.

De Tomasi, F., Blanco, A., and Perrone, M. R.: Raman lidar monitoring of extinction and backscattering of African dust layers and dust characterization, Appl. Optics, 42(9), 1699-1709, doi:10.1364/AO.42.001699, 2003. 
Devara, P. C. S., Pandithurai, G., Raj, P. E., and Sharma, S.: Investigations of aerosol optical depth variations using spectroradiometer at an urban station. Oune, India, J. Aerosol. Sci., 27, 621-632, 1996.

Di Donfrancesco, G., Cairo, F., Buontempo, C., Adriani, A., Viterbini, M., Snels, M., Morbidini, R., Piccolo, F., Cardillo, F., Pommereau, J. P., and Garnier, A.: Balloonborne Lidar for cloud physics studies, Appl. Optics, 42, 22, 5701-5708, 2006.

Di Sarra, A., Di Iorio, T., Cacciani, M., Fiocco, G., and Fuà, D.: Saharan dust profiles measured by lidar at Lampedusa, J. Geophys. Res., 106, D10, 335-347, 2001.

Dubovik, O., Smirnov, A., Holben, B.N., King, M.D., Kaufman, Y.J., Eck, T.F., and Slutsker, I.: Accuracy assessments of aerosol optical properties retrieved from Aerosol Robotic Network (AERONET) Sun and Sky radiance measurements, J. Geophys. Res., 105(D8), 9791-9806, 2000.

Dubovik, O. and King, M. D.: A flexible inversion algorithm for retrieval of aerosol optical properties from Sun and sky radiance measurements, J. Geophys. Res., 105, 20673-20696, 2002.

Eck, T. F., Holben, B. N., Ward, D. E., Mukelabai, M. M., Dubovik, O., Smirnov, A., Schafer, J. S., Hsu, N. C., Piketh, S. J., Queface, A., Le Roux, J., Swap, R. J., and Slutsker, I. : Variability of biomass burning aerosol optical characteristics in southern Africa during the SAFARI 2000 dry season campaign and a comparison of single scattering albedos estimates from radiometric measurements, J. Geophy. Res., 108(D13), 8477, doi:10.1029/2002JD002321, 2003.

Ferrare, R. A., Turner, D. D., Brasseur, L. H., Feltz, W. F., Dubovik, O., and Tooman, T. P.: Raman lidar measurements of the aerosol extinction to backscatter ratio over the Southern Great Plains, J. Geophys. Res., 106, 20333-20347 2001.

Fiebig, M., Petzold, A., Wandinger, U., Wendisch, M., Kiemle, C., Stifter, A., Ebert, M., Rother, T., and Leiterer, U.: Optical closure for an aerosol column: method, accuracy, and inferable properties applied to a biomass-burning aerosol and its radiative forcing, J. Geophys. Res., 107(D21), 8130, doi:10.1029/2000JD000192, 2002.

Forster, P., Ramaswamy, V., Artaxo, P., Berntsen, T., Betts, R., Fahey, D.W., Haywood, J., Lean, J., Lowe, D.C., Myhre, G., Nganga, J., Prinn, R., Raga, G., Schulz, M., and Van Dorland, R.: Changes in atmospheric constituents and in radiative forcing in Climate Change 2007: The Physical Science Basis, Contribution of Working Group I to the Fourth Assesment Report of the Intergovernmental Panel on Climate Change, edited by: Solomon, S. et al., 129-234, Cambridge Univ. Press, Cambridge, UK, 2007.

Gobbi, G. P., Barnaba, F., Giorgi, R., and Santacasa, A.: Altituderesolved properties of a Saharan dust event over Mediterranean, Atmos. Environ., 34, 5119-5127, 2000.

Hamonou, E., Chazette, P., Balis, D., Dulac, F., Schneider, X., Galani, E., Ancellet, G., and Papayannis, A.: Characterization of the vertical structure of Saharan dust export to the Mediterranean basin, J. Geophys. Res., 22257-2270, 1999.

Haywood, J. M. and Boucher, O.: Estimates of the direct and indirect aerosols: a review, Rev. Geophys., 38, 513-543, 2000.

Haywood, J., Francis, J., Osborne, S., Glew, M., Loeb, N., Highwood, E., Tanrè, D., Myhre, G., Formenti, P., and Hirst, E. : Radiative properties and direct radiative effect of Saharan dust measured by the C-130 aircraft during SHADE: 1. Solar spectrum, J. Geophy. Res., 108(D18), 8577, doi:10.1029/2002JD002687,
2003.

Haywood, J. M., Pelon, J., Formenti, P., Bharmal, N., Brooks, M., Capes, G., Chazette, P., Chou., C., Christopher, S., Coe, H., Cuesta, J., Derimian, Y., Desboeufs, K., Greed, G., Harrison, M., Heese, B., Highwood, E.J., Johnson, B., Mallet, M., Marticorena, B., Marsham, J., Milton, S., Myhre, G., Osborne, S.R., Parker, D. J., Rajot, J. L., Schulz, M., Silingo, A., Tanrè, D., and Tulet, P.: Overview of the Dust and Biomass-burning Experiment and African Monsoon Multidisciplinary Analysis Special Observing Period-0, J. Geophys. Res., 113, D00C17, doi:10.1029/2008JD010077, 2008.

Heese, B. and Wiegner, M. : Vertical aerosol profiles from Raman-depolarization lidar observations during the dry season AMMA field campaign, J. Geophys. Res., 113, D00C11, doi:10.1029/2007JD009487, 2008.

Immler, F. and Schrems, O.: Vertical profiles, optical and microphysical properties of Saharan dust layers determined by a ship-borne lidar, Atmos. Chem. Phys., 3, 1353-1364, doi:10.5194/acp-3-1353-2003, 2003.

Johnson, B., Osborne, S., Haywood, J., and Harrison, M.: Aircraft measurements of biomass burning aerosol over West Africa during DABEX, J. Geophys. Res., 113, D00C06, doi:10.1029/2007JD009451, 2008.

Lèon, J.-F., Derimian, Y., Chiapello, I., Tanrè, D., Podvin, T., Chatenet, B., Diallo, A., and Deroo, C.: Aerosol vertical distribution and optical properties over M'Bour $\left(16.96^{\circ} \mathrm{W} ; 14.39^{\circ}\right.$ N), Senegal from 2006 to 2008, Atmos. Chem. Phys., 9, 92499261, doi:10.5194/acp-9-9249-2009, 2009.

Kim, S.-W., Chazette, P., Dulac, F., Sanak, J., Johnson, B., and Yoon, S.-C.: Vertical structure of aerosols and water vapor over West Africa during the African monsoon dry season, Atmos. Chem. Phys., 9, 8017-8038, doi:10.5194/acp-9-8017-2009, 2009.

Magi, A., Hobbs, P. V., Schmid, B., and Redemann, J.: Vertical profiles of light scattering, light absorption and single-scattering albedo during the dry, biomass burning season in southern Africa and comparisons of in situ and remote sensing measurements of aerosol optical depths, J. Geophys. Res., 108(D13), D00C06, doi:10.1029/2002JD002361, 2003.

Marticorena, B. and Bergametti, G.: Two-year simulations of the seasonal and interannual changes of the Saharan dust emissions, Geophys. Res. Lett., 23(15), 1921-1924, 1996.

Mattis, I., Ansmann, A., Müller, D., Wandinger, U., and Althausen, D.: Dual-wavelength Raman lidar observations of the extinctionto backscatter ratio of Saharan dust, Geophys. Res. Lett., 29(9), 1306, doi:10.1029/2002GL014721, 2002.

Mishcenko, M. I., Kahn, R. A., and West, R. A.: Modeling phase functions for dustlike tropospheric aerosols using a shape mixture of randomly oriented polydisperse spheroids, J. of Geophys. Res., 102(D14), 831-847,1997.

Mona, L., Amodeo, A., Pandolfi, M., and Pappalardo, G.: Saharan dust intrusions in the Mediterranean area : Three years of Raman lidar measurements, J. Geophys. Res., 111(D16), D16203.1D16203.13, 2006.

Moulin, C., Lambert, C., Dulac, F., and Dayan, U. : Control of atmospheric export of dust from North Africa by the North Atlantic Oscillation, Nature, 387, 691-694, 1997.

Osborne, S., Johnson, B., Haywood, J., Baran A., Harrison, M., and McConnell, C.: Physical and optical properties of mineral 
dust aerosol during the Dust and Biomass-burning Experiment, J. Geophys.Res., 113, 2008.

Pelon, J., Mallet, M., Mariscal, A., Goloub, P., Tanrè, D., Bou Karam, D., Flamant, C., Haywood, J., Pospichal, B., and Victori, S.: Microlidar observations of biomass burning aerosol over Djougou (Benin) during African Monsoon Multidisciplinary Analysis Special Observation Period 0: Dust and Biomass Burning Experiment, J. Geophys. Res., 113, D00C18, doi:10.1029/2008JD009976, 2008.

Prospero, J. M. and Carlson, T. N.: Vertical and areal distribution of Saharan dust over the western equatorial North Atlantic Ocean, J. Geophys. Res., 77, 5255-5265, 1972.

Prospero, J. M., Ginoux, P., Torres, O., Nicholson, S. E. and Gill, T. E.: Environmental characterization of global sources of atmospheric soil dust identified with the Nimbus 7 total ozone mapping spectrometer (TOMS) absorbing aerosol product, Rev. Geophys., 40, 1002, doi:10.1029/2000RG000095, 2002.

Rajot, J. L.: Wind blown sediment mass budget of Sahelian village land units in Niger", Bulletin de la Societe Géologique de France, 172(5), 523-531, 2001.

Rajot, J. L., Alfaro, S., Desboeufs, K., Chevaillier, S., Formenti, P., Triquet, S., Chatenet, B., Gaudichet, A., Journets, E., Maman, A., Mouget, N., and Zakou, A.: AMMA dust experiment: An overview of measurements performed during the dry season special observation period (SOP0) at the Banizoumbou (Niger) supersite, J. Geophys. Res., 113, D00C14, doi:10.1029/2008JD009906, 2008.

Raut, J.-C. and Chazette, P.: Radiative budget in the presence of multi-layered aerosol structures in the framework of AMMA SOP-0, Atmos. Chem. Phys., 8, 6839-6864, doi:10.5194/acp-86839-2008, 2008.

Reagan, J. A., McCormick, M. P, and Spinhirne, J. D.: Lidar sensing of aerosols and clouds in the troposphere and stratosphere, Proc. IEEE, 77(3), 433-448, 1989.

Real, E., Orlandi, E., Law, K. S., Fierli, F., Josset, D., Cairo, F., Schlager, H., Borrmann, S., Kunkel, D., Volk, C. M., McQuaid, J. B., Stewart, D. J., Lee, J., Lewis, A. C., Hopkins, J. R., Ravegnani, F., Ulanovski, A., and Liousse, C.: Cross-hemispheric transport of central African biomass burning pollutants: implications for downwind ozone production, Atmos. Chem. Phys., 10, 3027-3046, doi:10.5194/acp-10-3027-2010, 2010.
Redelsperger, J.-L., Thorncroft, C. D., Diedhiou, A., Lebel, T., Parker, D. J., and Polcher, J.: African Monsoon Multidisciplinary Analysis: An International Research Project and Field Campaign, B. Am. Meteor. Soc., 87, 1739-1746., doi:10.1175/BAMS-87-12-1739, 2006.

Schmid, B., Redemann, J., Russell, P.B., Hobbs, P. V., Hlavka, D. L., McGill, M. J., Holben, B. N., Welton, E. J., Campbell, J. R., Torres, O., Kahn, R. A., Diner, D. J., Helmlinger, M. C., Tanré, D., Haywood, J. M., Pelon, J., Lon, J. F., Chatenet, B., Formenti, P., Francis, P., Goloub, P., Highwood, E. J., and Myhre, G.: Measurement and modeling of the Saharan dust radiative impact: overview of the SaHAran Dust Experiment (SHADE), J. Geophys. Res., 108(D13) 8574, doi:10.1029/2002JD003273, 2003.

Stachlewska, I. S., Neuber, R., Lampert, A., Ritter, C., and Wehrle, G.: AMALi - the Airborne Mobile Aerosol Lidar for Arctic research, Atmos. Chem. Phys., 10, 2947-2963, doi:10.5194/acp10-2947-2010, 2010.

Swap, R., Garstang, M., Greco, S., Talbot, R., and Kallberg, P.: Saharan dust in the Amazon Basin, Tellus, 44B, 133-149,1992.

Swap, R. J., Annegarn, H. J., Suttles, J. T., King, M. D., Platnick, S., Privette, J. L., and Scholes, R. J.: Africa burning: A thematic analysis of the Southern African Regional Science Initiative (SAFARI 2000), J. Geophys. Res., 108(D13), 8465, doi:10.1029/2003JD003747, 2003.

Tafuro, A. M., Barnaba, F., and De Tomasi, F.: Saharan dust particle properties over the central Mediterranean, Atmos. Res., 81, 6793, 2006.

Tanrè, D., Haywood, J., Pelon, J., Lèon, J.-F., Chatenet, B., Formenti, P., Francis, P., Goloub, P., Highwood, E., and Myhre, G. Measurement and modeling of the Saharan dust radiative impact: Overview of the Saharan Dust Experiment (SHADE), J. Geophys. Res., 108(D18), 8574-8586, doi:10.1029/2002JD003273, 2003.

Wandinger, U., Müller, D., Böckmann, C., Althausen, D., Matthias, V., Bösenberg, J., Wei, V., Fiebig, M., Wendisch, M., Stohl, A., and Ansmann, A.: Optical and microphysical characterization of biomass-burning and industrial-pollution aerosols from multi wavelength lidar and aircraft measurements, J. Geophys. Res., 107, D21, 8125, doi:10.1029/2000JD000202, 2002.

Winker, D. M., Hunt, W. H., and McGill, M. J.: Initial performance assessment of CALIOP, Geophy. Res. Letter, L19803, doi:10.1029/2007GL030135, 2007. 